\title{
Spiritual values shape taxonomic diversity, vegetation composition, and conservation status in woodlands of the Northern Zagros, Iran
}

\author{
Zahed Shakeri $^{1}$, Kyumars Mohammadi-Samani $^{2,3}$ Erwin Bergmeier $^{4}$ and Tobias Plieninger $^{1,5}$
}

\begin{abstract}
Sacred groves are under-researched in Muslim countries so that their overall contribution to biodiversity conservation remains unknown. We studied 22 sacred groves and 45 surrounding woodlands in Northern Zagros, Iran, to compare taxonomic diversity, vegetation composition, and the conservation status of plant species. Sacred groves had higher taxonomic diversity and a more valuable species pool by sheltering numerous endangered plant species. Multivariate analysis indicated a substantial difference in the vegetation composition of sacred groves and surrounding woodlands. Traditional deliberate protection (because of religious values) plus some environmental variables were the main drivers of the distinct vegetation composition of sacred groves. Sacred groves are the only remains of old-growth forests in the border regions of Iran and Iraq and they are important refuges of biocultural diversity. To better link the conservation of nature and culture, we recommend encouraging local people to preserve spiritual values, myths, and taboos around sacred groves.
\end{abstract}

Key Words: endangered species; in situ conservation; religious beliefs; sacred groves; silvopastoral practices

\section{INTRODUCTION}

Many protected areas in developing countries have experienced conflicts and lack local community support because of often missing consideration of local people's demands and interests in protected area management (Bhagwat and Rutte 2006). However, there is plenty of evidence that people have actively protected parts of their local landscapes for generations for cultural or spiritual reasons (Wild et al. 2008). Such sacred natural sites include mountains, water sources, trees, groves, and forests and are found all over the world (Dafni 2007). Many sacred natural sites have been recognized as hotspots of biocultural diversity in which spiritual/religious, cultural, and biological values are interlinked (Frascaroli and Verschuuren 2016). Because of their wide spatial distribution, their location in agricultural landscapes where formal protected areas are underrepresented, and their preservation status, sacred natural sites have the potential to be integrated as important stepping stones into formal conservation plans (Wild et al. 2008, Deil et al. 2014).

The relationships between faith and nature conservation values are deeply rooted and have been well recognized by conservation institutions, e.g., UNESCO, IUCN, and WWF (Bhagwat et al. 2011). Among 11 mainstream faiths, eight of them (Baha'i, Buddhism, Daoism, Hinduism, Jainism, Shinto, Sikhism, and Zoroastrianism) regard nature as divine or sacred (Dudley et al. 2009). Christian, Jewish, and Muslim theology see the environment as "God's creation to serve humankind" (White 1967), realizing that this could hardly be interpreted as wasteful use but rather implies conservation and careful treatment of its resources. The deep human-nature relationships underlying these faiths are materialized in a high number of sacred natural sites in central, east, and south Asia (Dudley et al. 2009), most notably in India (Ormsby and Bhagwat 2010), China, Thailand, and Japan (Verschuuren and Furuta 2016). Different social-ecological aspects of sacred natural sites have been studied in many parts of the world (Dudley et al. 2010, Cardelús et al. 2013, Frascaroli and Verschuuren 2016). Hardly any social or ecological studies have been carried out on sacred natural sites in Muslim countries, with very few exceptions, e.g., sacred groves in Morocco (Jäckle et al. 2013) and graveyards in Turkey (Löki et al. 2015).

Sacred natural sites have persisted via veneration of saints from pre-Christian to Christian, pre-Jewish to Jewish, and pre-Muslim to Muslim societies (Dafni 2007). For instance, in the Kurdish territory of Iran, sacred natural sites are rooted in ancient religions like Mithraism and Zoroastrianism. Until recently, almost every village maintained its own sacred place, e.g., a part of the forest, a valley, a mountain summit, or a spring with its surroundings (Shakeri and Mostafa 2018), despite the Arab conquest of the Persian Empire in AD 7th-8th centuries (Morony 2019) and the subsequent conversion of Kurdish people to Islam in AD 16th-17th centuries (Roohi 2014). Most sacred natural sites in Kurdistan served as burial grounds to the villages and they are seen as an abode of their ancestors' body and soul; therefore, they have been strictly protected by local people as "sacred groves" (Shakeri 2006). Generally, one or several people endow part of their woodland to serve as a new cemetery to the village (i.e., new sacred grove) when there is no more burial place in the old sacred grove. Thereafter, the new sacred grove will be under the same maintenance and protection as the old ones by local communities. Sacred groves are protected through taboos and strict rules, including the prohibition of livestock grazing, hunting, and collection of fodder, edible plants for commercial use, lumber, and fuel-wood (Plieninger et al. 2020). Additionally, local people protect sacred groves from land encroachment and wildfires by light pollarding (approximately every 10 years) and collecting dead branches to establish a hedge around the sacred grove.

Sacred groves are embedded in a mosaic landscape of oak woodpastures and traditional farmlands (Figure A1.1a) that developed through a long history of civilization in the Zagros Mountains of

${ }^{1}$ Faculty of Organic Agricultural Sciences, University of Kassel, Witzenhausen, Germany, ${ }^{2}$ Department of Forestry, Faculty of Natural Resources, University of Kurdistan, Sanandaj, Iran, ${ }^{3}$ Center for Research and Development of Northern Zagros Forestry, Baneh, Iran, ${ }^{4}$ Department of Vegetation and Phytodiversity Analysis, Georg-August-Universität Göttingen, Germany, ${ }^{5}$ Department of Agricultural Economics and Rural Development, Georg-August-Universität Göttingen, Germany 
Iran (Izady 1994). Local peoples' livelihoods are heavily dependent on natural resources, expressed in a traditional landuse system called "Galazani" (Figure A1.1b). In this system, each family manages part of the woodland by applying traditional silvopastoral techniques (Valipour et al. 2014). Goats and sheep are the dominant livestock in the region. They feed on ground vegetation during the growing season and depend on dried oak leaves (leaf hay) as winter fodder. Local people pollard oak trees in specific three- to four-year rotations to sustain leaf fodder for their livestock (Ghazanfari et al. 2004).

The Zagros Mountains are part of the Irano-Anatolian vegetation region. They occupy about $10 \%$ of Iran but harbor more than $25 \%$ of the country's total number of plant species and are an important biocultural refugium; however, less than $1 \%$ of the total land is designated as protected area (Darvishsefat 2006). In this context, sacred groves gain considerable importance as biodiversity-rich islands within a matrix of increasingly intensified land uses. Sacred groves are patchy and cover small areas in the Zagros region (from 0.3 to $7.0 \mathrm{ha}$ ), but are of considerable conservation importance as they harbor the only remaining old-growth remnants of climax forests (Shakeri and Mostafa 2018). First studies have described the structure and diversity of woody species in sacred groves of Kurdistan (Shakeri et al. 2009, Ghahramany et al. 2017), but the composition and diversity of ground vegetation and the contribution of sacred groves to biodiversity conservation remained unknown. To better understand the contribution of sacred groves to "in situ conservation", we need comparative data from sacred groves and their surrounding silvopastoral woodlands. To fill this gap, the present study aimed to compare the taxonomic diversity, vegetation composition, and conservation status of plants between sacred groves and surrounding woodlands. We formulated the following research questions:

1. How does taxonomic diversity of sacred groves differ from that of surrounding woodlands?

2. How distinct is the vegetation composition of sacred groves from surrounding woodlands?

3. Which are the most important environmental variables affecting vegetation composition?

4. What is the conservation status of plants in sacred groves and surrounding woodlands?

\section{METHODS}

\section{Study area}

The study area, Baneh, is located in the northern Zagros mountain range of Kurdistan province, western Iran $\left(35^{\circ} 45^{\prime}\right.$ to $36^{\circ} 10^{\prime} \mathrm{N}$ and $45^{\circ} 40^{\prime}$ to $46^{\circ} 10^{\prime}$ E; Fig. 1 ). The Baneh area ranges from 1000 to $3200 \mathrm{~m}$ in altitude, with an average elevation of $1550 \mathrm{~m}$ above sea level. Baneh receives $675 \mathrm{~mm}$ of annual precipitation, most of it as snow in winter. It experiences warm, dry summers and cold winters typical of a sub-Mediterranean subcontinental climate with an average annual temperature of $13.7{ }^{\circ} \mathrm{C}$ (Mohammadi Samani et al. 2020). The soil depths depend on physiographic conditions (shallow on steep slopes and degraded lands, deep in depressions and flat areas), generally with sandy or clay-loam texture that overlay calcareous, shale, or schist bedrocks (Mohammadi Samani et al. 2020).
Fig. 1. Location of selected sacred groves (blue stars) and surrounding woodlands (red circles) in Baneh, northwest Iran.

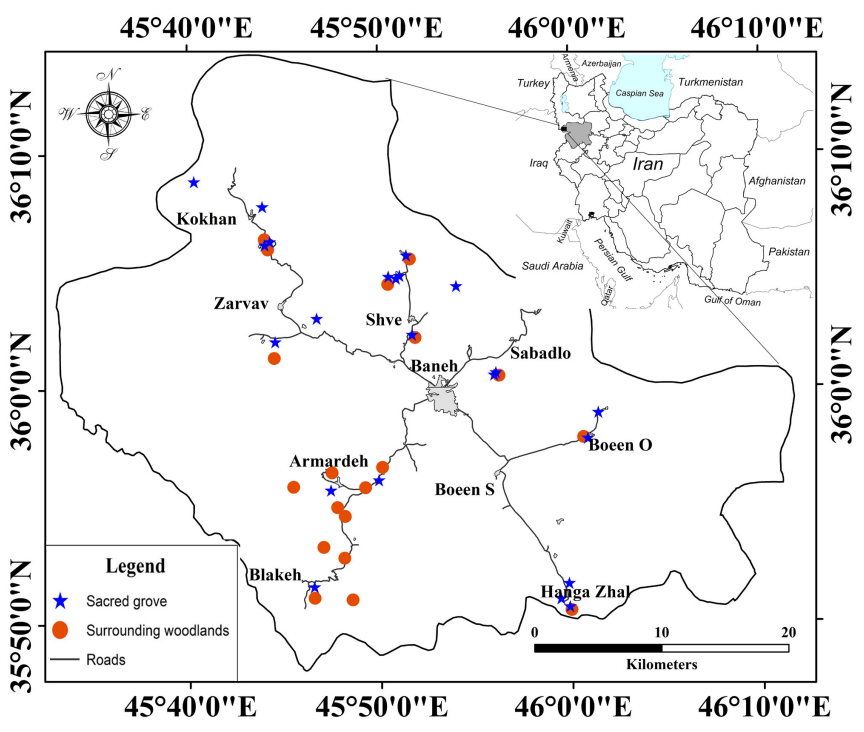

Oak-dominated woodlands (Lebanon oak, Quercus libani and Aleppo oak, Quercus infectoria) are the most widespread vegetation of the northern Zagros range and they mainly serve as grazing areas for local herds. Sacred groves, the only patches of old-growth forests, are wooded areas surrounding cemeteries, sanctuaries, or tombs without grazing and human disturbances, such as pollarding. Their spatial distribution is imposed by the distribution of villages and their surface area range from 2000 to $80,000 \mathrm{~m}^{2}$. There are a total of 190 villages in the Baneh region and each one has between one and three sacred groves.

\section{Data collection}

We identified sacred groves and the surrounding woodlands in the region by using topographic maps and satellite imagery. The sacred groves were located between $50 \mathrm{~m}$ and $1 \mathrm{~km}$ from the villages. In total, we visited 58 villages and 120 sacred groves. From these, we focused on sacred groves larger than 0.5 ha with little or no soil disturbance (caused by ongoing burial practices or treasure hunting excavations). We then selected surrounding woodlands with trees that had been regularly pollarded during the last three decades and where the understory had not been cultivated. We obtained permission from the village councils to sample sacred groves and from local owners to sample their woodlands. In cases in which a sacred grove was not surrounded by eligible woodland or in which the owners did not permit access, we searched for slightly more distant woodlands in a similar physiographic, soil, and vegetation condition. Finally, we selected 22 sacred groves and 45 surrounding woodlands and sampled 122 vegetation relevés. We took only one relevé in homogenous and several relevés in sacred groves and surrounding woodlands with heterogeneous physiography and vegetation, leading to a total of 32 relevés in sacred groves and 90 relevés in surrounding woodlands. The minimal area approach suggested by MüllerDombois and Ellenberg (2002) indicated a minimal plot size of $280 \mathrm{~m}^{2}$ and $225 \mathrm{~m}^{2}$ for sacred groves and surrounding woodlands, respectively. We consistently used a plot size of $300 \mathrm{~m}^{2}$ in both types. 
We carried out vegetation sampling from May to June in 2016 and 2017. We recorded all vascular plant species and collected one voucher per species for further determination and analysis in the lab. Plant species and subspecies were determined in the herbarium of the Forest and Rangelands Research Institute, Sanandaj, Kurdistan Province, using the Floras of Iran and Iraq (Townsend and Guest 1974, Assadi et al. 1989). These floras are also the taxonomic reference works of this paper. Voucher specimens were stored in the herbarium HKS of the Kurdistan Agricultural and Natural Resources Research and Education Center. We used the Londo decimal scale to estimate the coverabundance of each species per plot (Londo 1976). We also measured geographical position and environmental variables, including altitude (m a.s.1.), inclination (\%), aspect, crown canopy percentage, bare soil $(\%)$, and litter depth $(\mathrm{cm})$. We collected five mixed representative soil samples at a depth of $0-10 \mathrm{~cm}$ in the four corners and center of each relevé. Soil texture, $\mathrm{pH}, \mathrm{EC}(\mu \mathrm{S} /$ $\mathrm{cm})$, total nitrogen $(\%)$, phosphorus $(\mathrm{mg} / \mathrm{kg})$, potassium $(\mathrm{mg} / \mathrm{kg})$, and organic carbon $(\%)$ were measured in the lab.

\section{Data analyses}

To evaluate taxonomic diversity, we calculated the Shannon $(\mathrm{H})$, Simpson $\left(D_{1}\right)$, and Pielou $(J)$ indices by using the vegan package in $\mathrm{R}$. We then compared the differences between diversity indices of sacred groves and surrounding woodlands by a student t-test after checking that assumptions of normality $(p>0.05)$ and homogeneity of variances $(p>0.05)$ were fulfilled. We estimated beta diversity by the Bray-Curtis dissimilarity index in the betapart package (Baselga and Orme 2012) and then performed an analysis of variance (ANOVA) to test for significant differences between sacred groves and surrounding woodlands. The species pool size and numbers of overlooked species were estimated by the Chao estimator $\left(\mathrm{f}_{0}\right)$ in the vegan package (Oksanen et al. 2010).

To compare and illustrate the vegetation composition of sacred groves and surrounding woodlands, we applied nonmetric multidimensional scaling (NMDS) with the Bray distance and number of axes fixed to three. We assessed goodness-of-fit of this analysis with the stress value and Shepard diagram (Young 2013). PERMANOVA was used to test the significance of NMDS with 999 permutations. Then, 15 environmental and soil variables on NMDS were fitted to relate the environmental factors to vegetation composition (Legendre and Legendre 2012). A tri-plot of species, samples, and environmental variables (with only significant variables) was constructed to illustrate their correlations in the ordination space. All analyses were carried out in $\mathrm{R}$ 3.6.1 ( $\mathrm{R}$ Core Team 2019). We assessed the national conservation status of plant species by using the Red Data Book of Iran and other published literature (Jalili and Jamzad 1999, Willis 2001).

\section{RESULTS}

\section{Taxonomic diversity}

We identified a total of 254 vascular plant species belonging to 163 genera of 45 families; among them, 114 species were found uniquely in sacred groves, 46 species uniquely in surrounding woodlands, and 94 species occurred in both (Table A2.1). The highest species numbers were recorded from the families of Asteraceae (47), Fabaceae (32), Poaceae (16), Apiaceae (16), and Caryophyllaceae (12). Four species of Orchidaceae were only found in sacred groves. Hemicryptophytes, therophytes, and cryptophytes with 39,35 , and $20 \%$, respectively, were the most abundant plant life forms. We found 208 and 140 plant species in sacred groves and surrounding woodlands, respectively, and the nonparametric Chao estimator predicted total species numbers of $250 \pm 15$ (SE) and $153 \pm 7(\mathrm{SE})$, respectively.

Significant differences in all diversity indices were found between sacred groves and the surrounding woodlands $(p<0.001)$. Species richness, species evenness, and species diversity were significantly higher in sacred groves (Table 1). Beta diversity of sacred groves was also significantly higher $(0.402 \pm 0.117)$ than that of surrounding woodlands $(0.209 \pm 0.084)$ (Fig. 2).

Table 1. Student t-test results for species richness, Shannon, Simpson, and Pielou indices of sacred groves (32 relevés) and the surrounding woodlands ( 90 relevés).

\begin{tabular}{|c|c|c|c|c|c|}
\hline & $\begin{array}{l}\text { Degree of } \\
\text { freedom }\end{array}$ & $\mathrm{T}$ & P-value & $\begin{array}{c}\text { Sacred } \\
\text { groves } \\
(\mathrm{Mean} \pm \mathrm{SD})\end{array}$ & $\begin{array}{c}\text { Surrounding } \\
\text { woodlands } \\
\text { (Mean } \pm \text { SD) }\end{array}$ \\
\hline $\begin{array}{l}\text { Species } \\
\text { richness }\end{array}$ & 49.4 & 7.164 & $0.001 * * *$ & $33.4 \pm 6.6$ & $23.9 \pm 5.8$ \\
\hline $\begin{array}{l}\text { Shannon- } \\
\text { Weaver } \\
\text { index }\end{array}$ & 46.9 & 5.358 & $0.001 * * *$ & $2.798 \pm 0.351$ & $2.427 \pm 0.290$ \\
\hline $\begin{array}{l}\text { Simpson } \\
\text { index }\end{array}$ & 60.4 & 4.248 & $0.007 * *$ & $0.901 \pm 0.052$ & $0.854 \pm 0.058$ \\
\hline $\begin{array}{l}\text { Pielou } \\
\text { index }\end{array}$ & 46.3 & 2.067 & $0.044^{*}$ & $0.799 \pm 0.072$ & $0.770 \pm 0.058$ \\
\hline
\end{tabular}

Fig. 2. Box-plot of the measure of beta diversity for sacred groves (SG, red) and surrounding woodlands (SW, blue; ANOVA, $\mathrm{p}<0.001)$.

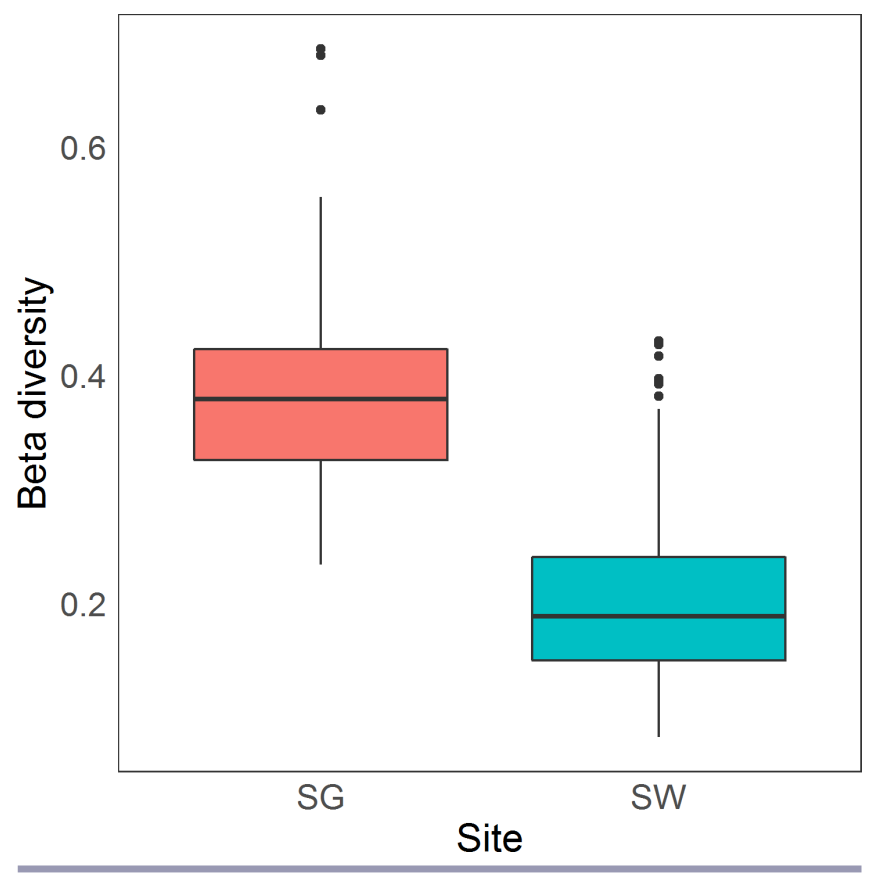




\section{Vegetation composition}

The stress value for NMDS analysis was equal to 0.119 and the Shepard plot showed that original dissimilarities were well preserved in the analysis (Fig. A1.2). Vegetation composition between sacred groves and surrounding woodlands was significantly different based on PERMANOVA analysis (Table 2). These two groups were differentiated along the first axis of the NMDS ordination space (Fig. 3).

The following species were found much more commonly in sacred groves than in surrounding woodlands: Malabaila sekakul,

Table 2. PERMANOVA results for the vegetation composition of sacred groves and surrounding woodlands.

\begin{tabular}{lcccccc}
\hline \hline & $\begin{array}{c}\text { Degree } \\
\text { of } \\
\text { freedom }\end{array}$ & Sums of Sqs & $\begin{array}{c}\text { Mean } \\
\text { Sqs }\end{array}$ & F. Model & $\mathrm{R}^{2}$ & $\mathrm{P}(>\mathrm{F})$ \\
\hline Site & 1 & 5.393 & 5.393 & 21.889 & 0.154 & $0.001 * * *$ \\
Residuals & 120 & 29.565 & 0.246 & & 0.845 & \\
Total & 121 & 34.958 & & & 1.000 & \\
\hline
\end{tabular}

*** $\mathrm{P}<0.001$

Fig. 3. Nonmetric multidimensional scaling (NMDS) convex hull of relevés between sacred groves (SG) and surrounding silvopastoral woodlands (SW). Only species scores are depicted and to prevent overcrowding of the diagram, species names are not displayed.

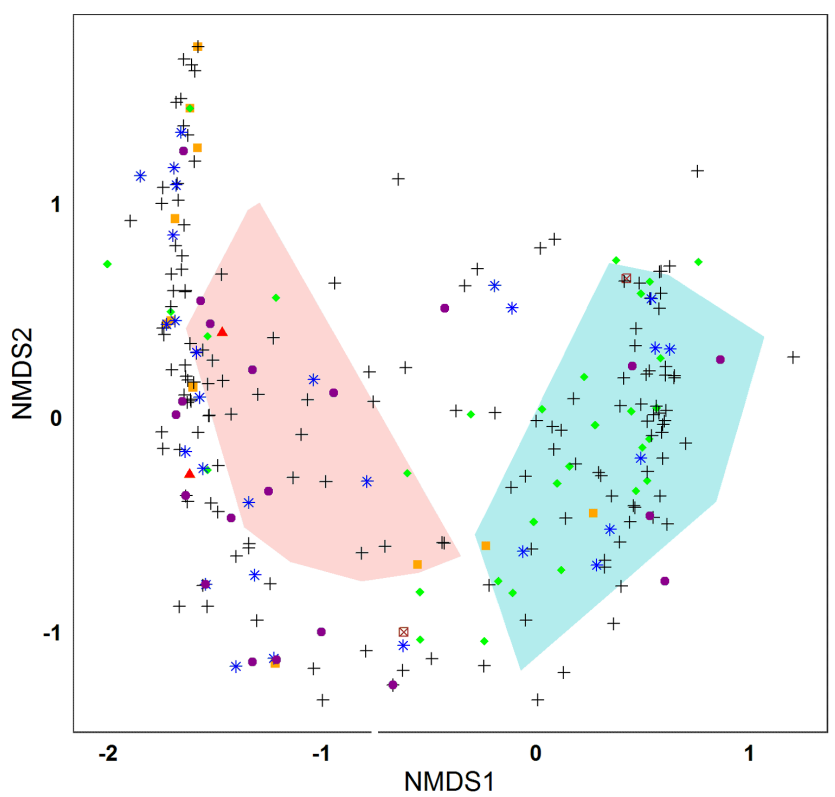

\begin{tabular}{|c|c|c|c|}
\hline \multirow[b]{2}{*}{$\Delta$} & \multicolumn{2}{|c|}{ Conservation } & \multirow{2}{*}{$\begin{array}{l}\text { site } \\
\qquad s\end{array}$} \\
\hline & Critically endangered & - Least concern & \\
\hline$\otimes$ & Data deficient & * Near threatened & SW \\
\hline " & Endangered & $\begin{array}{l}+\quad \text { Not evaluated } \\
\text { - Vulnerable }\end{array}$ & \\
\hline
\end{tabular}

Prangos ferulacea, Bellevalia olivieri, Muscari comosum, Alliaria petiolata, Lonicera nummulariifolia, Silene latifolia, Salvia bracteata, Cerasus microcarpa, Crataegus pontica, and Rosa canina. Most are species of shrubby undergrowth or other palatable plants of deep soil, plus a few exceptions, such as Bromus sterilis and Galium aparine. Conversely, the surrounding woodlands showed much higher frequencies of Achillea wilhelmsii, Arenaria serpyllifolia, Velezia rigida, Trifolium purpureum, Aegilops triuncialis, Bromus danthoniae, Bromus tectorum, Heteranthelium piliferum, and Ziziphora capitata, which are mostly annual plants of disturbed ground or perennial grazing indicators, e.g., Poa bulbosa.

\section{Environmental drivers of vegetation composition}

Fitting environmental variables on the NMDS ordination space resulted in 14 significant variables. Litter depth $(\mathrm{cm})$, crown canopy $(\%)$, organic carbon $(\%)$, nitrogen $(\%)$, and sand $(\%)$ positively pointed out toward sacred groves while other variables including aspect, altitude (a.s.1.), inclination (\%), potassium (mg/ $\mathrm{kg}$ ), phosphorus (mg/kg), bare soil (\%), $\mathrm{pH}$, silt (\%), and clay (\%) were toward the surrounding woodlands (Fig. 4).

Fig. 4. Tri-plot of species, relevés, and environmental variables resulting from fitting significant-environmental variables on nonmetric multidimensional scaling (NMDS) analysis of sacred groves (SG) and surrounding silvopastoral woodlands (SW). To prevent overcrowding in the diagram, species names and relevé numbers are not shown.

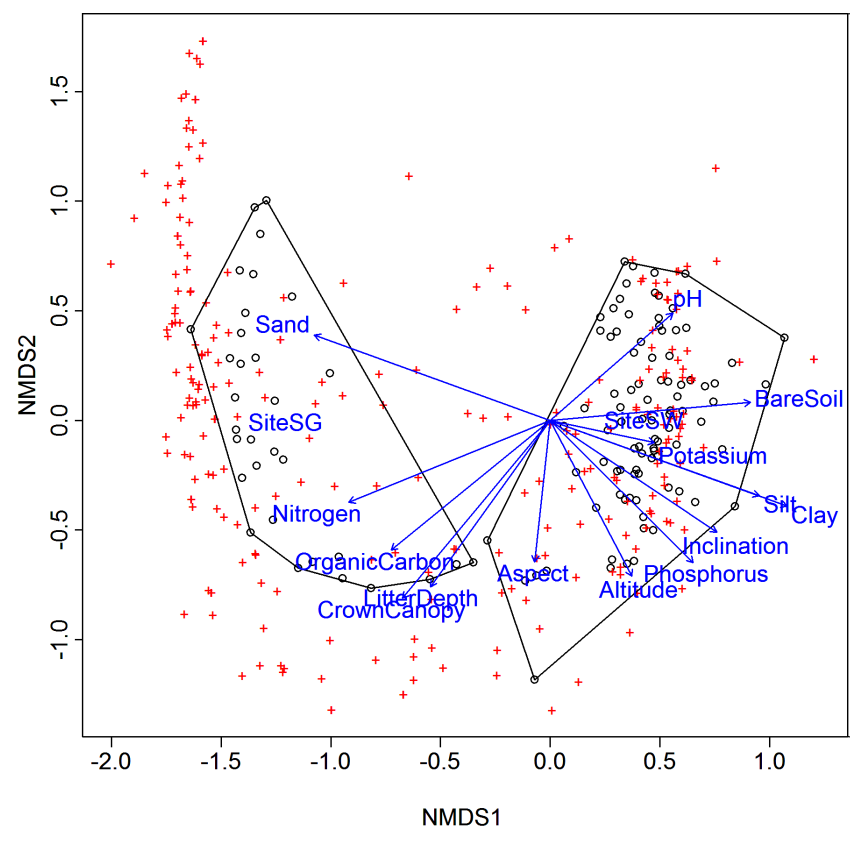

\section{Conservation status}

Out of the 254 species identified, $161(63.4 \%)$ could not be evaluated according to their national conservation status (Jalili and Jamzad 1999, Willis 2001). Two species $(0.8 \%)$ were data deficient, $31(12.2 \%)$ were of least concern, $29(11.4 \%)$ near threatened, $20(7.9 \%)$ vulnerable, $11(4.3 \%)$ endangered, and two $(0.8 \%)$ were in critically endangered categories (Table A2.1). All 
11 endangered species (woodland couch, Elymus panormitanus; a Southwest Asian species of spurge, Euphorbia macrocarpa; the imperial fritillaries Fritillaria imperialis and Fritillaria straussii; the bee orchids Ophrys reinholdii subsp. straussii and Ophrys sphegodes subsp. transhyrcana; the recently described regional endemic star-of-Bethlehem, Ornithogalum sanandajense; some near-eastern species of skullcap, Scutellaria condensata subsp. pycnotricha; saw-wort, Serratula grandifolia; and the goat'sbeards Tragopogon latifolius and Tragopogon buphthalmoides) and two critically endangered narrowly endemic garlic species (Allium hooshidaryae and Allium saralicum), with a further 15 of the vulnerable, 27 of the near-threatened, and 25 of the least concern species were located in sacred groves. Whereas in the surrounding woodlands, 25 species were of least concern, 14 near threatened, 12 vulnerable, and three endangered (Elymus panormitanus and two Tragopogon species; see also Table A2.1).

\section{DISCUSSION}

\section{Taxonomic diversity}

Diversity and understory plant composition across Zagros forests have remained unknown in the literature because of inaccessibility (poor road connection) and difficulties in identifying plants to the species level. This study is, to our knowledge, the first comparative investigation of ground vegetation of sacred groves and surrounding woodlands in this global biodiversity hotspot. We found that 22 sacred groves in Baneh area comprised $20 \%$ of the flora in the whole northern Zagros region (208 out of approximately 1000 species; Assadi et al. 1989). Sacred groves have preserved ecological and cultural values around the world for many centuries (Bhagwat and Rutte 2006, Frascaroli et al. 2016), but their importance is higher in countries with longer civilization history and more exploitative land use. In such areas, they often form near-natural islands that are surrounded by degraded lands (Dudley et al. 2010). Approximately 250 sacred groves exist in Baneh county alone, with a density of 16 sacred groves per $100 \mathrm{~km}^{2}$ (Shakeri 2006). Because of the endowment of new woodlands by local people to serve as sacred groves, their number is growing continuously. Our research highlights that, in relation to their small area, they harbor a disproportionally high number of unique and valuable species.

Sacred groves had significantly higher species richness, Shannon, Simpson, Pielou diversity indices, and beta diversity than the surrounding woodlands, confirming findings on the importance of sacred groves from other parts of the world for conserving biodiversity (Mgumia and Oba 2003, Frascaroli et al. 2016). Globally, sacred groves have low rates of anthropo-zoogenic disturbance because of local long-term protection (Allendorf et al. 2014); in northern Zagros, this protection seems highly effective thus far, as local people strongly embrace conservation values, taboos, and practices for sacred groves (Plieninger et al 2020). For example, local rules strictly interdict collecting firewood, hunting, livestock grazing, and commercial collection of fruits and plants in sacred groves, despite the high dependence of local people on natural resources. Although the surrounding woodlands are almost depleted of deadwood, litter, and plant debris, high stocks of deadwood and litter can increase soil nitrogen in sacred groves (Shakeri 2006), which adds to the overall habitat diversity of the landscape and supports species that are not otherwise found.
Silvopastoral activities, such as overly high grazing pressure and frequent pollarding, can cause lower woodland indicator species diversity; heavy grazing reduces the diversity of palatable plants and changes the abundance and dominance of species (Papanikolaou et al. 2011). Pollarding of oak trees reduces the tree canopy up to $20 \%$ and results in leaf area index reduction (from 1.92 in sacred groves to 0.33 in pollarded stands; Abbasi et al. 2017). Increased insolation, together with heavy grazing in woodlands, alter soil physical and chemical properties (Sharrow 2007, Mohammadi Samani et al. 2020), which may subsequently level habitat variation and reduce taxonomic diversity (Orefice et al. 2017). Because of higher canopy cover and habitat heterogeneity and lower soil disturbance, sacred groves support shade-tolerant species. They contribute to beta and landscapescale diversity (Mgumia and Oba 2003, Frascaroli et al. 2016), shelter hidden diversity (Pärtel 2014), and may even harbor unrecognized plant and/or fauna taxa new to science, e.g., two newly identified mite species from sacred groves of Kurdistan (Babaeian et al. 2019, Paktinat-Saeij et al. 2020).

\section{Vegetation composition}

Despite the fact that both sacred groves and the surrounding woodlands are likely to originate from the same class of zonal vegetation, i.e. Quercetea persicae (Zohary 1963), sacred groves are now islands of old-growth forests surrounded by silvopastoral woodlands with significantly distinct vegetation composition and structure. Other studies also addressed the dissimilarity in species composition between sacred groves and the surrounding managed lands and typically found much greater microhabitat heterogeneity in sacred groves (Deil et al. 2005, Bhagwat and Rutte 2006). Strict social taboos play an important role in providing ecological niches for shade-tolerant, nutrient-demanding, and sensitive species (Mgumia and Oba 2003).

Shrubs are key elements for many animal populations (Watson et al. 2011), but they are absent from overused silvopastoral woodlands. The Maraz goat, the main kind of livestock browsing in silvopastoral woodlands in northern Zagros, yields mohair, a valuable product. Therefore, people frequently clear oak sprouts and shrubs to prevent them from trapping the valuable Maraz goats' mohair (Shakeri 2006). Overgrazing can reduce the abundance of palatable and rare species and homogenize vegetation by shifting the community composition toward unpalatable forbs and annual grasses and herbs, such as Aegilops triuncialis, Bromus tectorum, Filago arvensis, Taeniatherum crinitum, Picnomon acarna, and Echinops orientalis (Bouahim et al. 2010). Spiritual values and traditional silvopastoral practices resulted in complementary vegetation in sacred groves and the surrounding woodlands. Sacred groves are thus unique in their combination of cryptophytes, nutrient-demanding, and woodland-specialist species, while the surrounding silvopastoral woodlands are rich in therophytes, ruderals, and light-demanding species.

\section{Environmental drivers of vegetation composition}

Five out of the 14 significant environmental variables driving the vegetation composition of sacred groves and surrounding woodlands (litter depth, crown canopy cover, soil organic carbon, nitrogen, and sand $\%$ ) were positively correlated to sacred groves. These environmental variables are a direct or indirect outcome of deliberate protection of sacred groves. Taboos that prevent 
livestock grazing, litter and deadwood collection, and pollarding have an important role in retaining tree canopy cover and increasing soil fertility. Plant litter is an important factor for the successful regeneration of oak trees, as resource for soil nutrient cycling (Córdova et al. 2018), and essential for soil faunal and fungal diversity (Wardle et al. 2006). Litter depth is negatively correlated with soil $\mathrm{pH}$ because accumulation of oak litter can increase soil acidity, due to the production of $\mathrm{CO}_{2}$ by microbial respiration (Singh and Gupta 1977), thus supporting rare acidophilic geophytes of Near East woodlands in sacred groves, such as Ornithogalum brachystachys and Allium macrochaetum, and a rare species of saw-wort, Serratula grandifolia (Gaderzadeh et al. 2015).

The positive correlation of tree canopy (\%) with soil organic carbon and nitrogen indicates the importance of canopy coverage for soil fertility in these forests (Isichei and Muoghalu 1992). Canopy coverage of sacred groves ranges from 40 to $90 \%$ (on average $70 \%$ ), while in the surrounding woodlands, it ranges between 10 and $40 \%$ (on average 20\%; Shakeri 2006). To maintain a balance in fodder production between trees and ground vegetation in silvopastoral systems, it is essential to keep the tree canopy cover around 20-30\% (Hartel and Plieninger 2014, Valipour et al. 2014). More light availability shifts the species pool toward light-demanding species. Accordingly, it is generally hard to find shade-tolerant species in the surrounding woodlands. In sacred groves, however, Southwest Asian chervil, Chaerophyllum macropodum; bellflower, Campanula involucrata; buttercup, Ranunculus constantinopolitanus; and broad-leaved helleborine, Epipactis helleborine are among the shade-tolerant plants that colonize beneath the closed canopy.

In the surrounding woodlands, livestock grazing can both directly and indirectly, i.e., by influencing chemical and physical soil variables, affect vegetation composition. High grazing rates can destroy soil texture, cause soil compaction and erosion (Daniel et al. 2002, Mohammadi Samani et al. 2020), and increase soil potassium and phosphorus content, owing to fecal deposition by livestock (James et al. 2007). Coarse-textured soils have higher infiltration rates (Schulz et al. 2016) and provide more suitable microhabitats for geophytes and nutrient-demanding species, such as Allium atroviolaceum, Chaerophyllum macropodum, Chaerophyllum aureum, Fritillaria straussii, Epipactis helleborine, and Symphytum kurdicum.

\section{Conservation status}

We found that sacred groves in Kurdistan shelter many plants of high conservation value. The fact that $60 \%$ of the studied plant species have not been evaluated based on IUCN conservation criteria suggests that this world region needs closer attention by conservation science. Still, of the evaluated plant species in the sacred groves, at the national level, 6\% were endangered and critically endangered, $13 \%$ were near threatened, and $7 \%$ were in vulnerable categories. Considering that most of these plants are endemic and restricted to the region, these sacred groves are particularly important for protecting threatened plant species on national and global levels. Specifically, two critically endangered garlic species Allium hooshidaryae and Allium saralicum have only recently been identified and have limited distribution in northern Zagros (Fritsch and Friesen 2002, Mashayekhi et al. 2005). We found these two species in three and four sacred groves, respectively. Ten out of 11 endangered species in sacred groves are medicinal and edible plants that have an important role in Kurdish cuisine and medicinal culture (Khezri 2002). In the surrounding woodlands, only $2 \%$ of the plants were in the threat category of endangered, $10 \%$ near threatened, and $9 \%$ vulnerable. The Mediterranean-Southwest Asian woodland grass, Elymus panormitanus and the Near East goat's-beards Tragopogon latifolius and Tragopogon buphthalmoides are endangered species shared between sacred groves and the surrounding woodlands. Both Tragopogon species are edible and of medicinal value, and Elymus panormitanus is appreciated for its forage value for livestock (Asri 2011).

Wild edible plants have important cultural and economic roles in rural areas of Iran. In fact, they are an important part of Kurdish cuisine; people use these plants in almost every dish (Khezri 2002). People are free to collect plant roots, bulbs, leaves, flowers, and fruits in the rural environment from grasslands and woodlands as low-cost food and also as traditional medicine. The food habits of the locals change during the year reflecting the plants' seasonality. During springtime, searching for wild edible plants and mushrooms is an important income source for some people and a popular hobby for many. The high demand for edible and medicinal plants has resulted in the extinction of some of these plants in specific localities and subsequent loss of local traditional knowledge (Khajoei Nasab and Khosravi 2014).

Many studies have emphasized the significance of sacred groves for the protection of endangered species (Bhagwat and Rutte 2006, Ray and Ramachandra 2010). This protection is mainly provided by general taboos that prevent people from hunting and collecting plants, fruits, or fuelwood and that prohibit livestock grazing (Allendorf et al. 2014); some taboos target specific plants or animal species (Dafni 2007). Although the main motivation of local people to preserve sacred groves is for their spiritual and cultural significance, still biodiversity and habitat conservation are a significant by-product of sacred groves, essential for many plant species. Among the endangered species, only the imperial fritillaries, Fritillaria imperialis and Fritillaria straussii, have high spiritual and cultural value for local people and generally people protect them no matter where they grow, because they are considered symbols of resurrection and love. Sacred groves in Kurdistan may harbor as yet unrecognized plants new to science (Maroufi 2010) and they are also important for protecting faunal diversity by providing suitable ecological niches for arthropods (Babaeian et al. 2019, Paktinat-Saeij et al. 2020) and vertebrates such as the Caucasian squirrel (Sciurus anomalus Gmelin) whose population has dramatically declined in Zagros because of habitat loss and overhunting (Sadeghi et al. 2017). Local people in Kurdistan have a deep connection to nature and they obtain most of their traditional food and medicine from local plants; nevertheless, they do not only abstain from collecting medicinal and edible plants from sacred groves but they also protect them from other disturbances, such as fire and livestock grazing. This traditional deliberate protection resulted in protecting the endangered species, unique biodiversity, and vegetation composition of sacred groves.

\section{CONCLUSION}

Our results showed that the values, taboos, and practices of sacred groves are expressed in significantly different conservation status, 
plant diversity, vegetation composition, and environmental conditions compared to more intensively used surrounding woodlands. Most notably, sacred groves hold higher taxonomic diversity and harbor many vulnerable and endangered plant species. The vegetation diversity and composition of sacred groves are an outcome of abiotic factors and active protection by local people. In the surrounding woodlands, heavy grazing and pollarding of oak trees supports light-demanding, ruderal, and unpalatable plants, whereas sacred groves are colonized by shadetolerant woodland specialists, including several endangered species.

Despite the small extent of sacred groves, our findings indicate that they can serve as an important complement to formal protected areas. Also, the vegetation composition and structure of sacred groves provides necessary baselines to reconstruct degraded areas. Given that sacred groves are globally endangered through resource-use pressures, poor governance, socioeconomic inequity, war, and corruption, the conservation status of the sacred groves studied here is remarkable. We recommend that this traditional protection be encouraged to conserve both nature and culture at one of the hotspots of biodiversity and civilization in the Middle East.

Responses to this article can be read online at: https://www.ecologyandsociety.org/issues/responses. php/12290

\begin{abstract}
Acknowledgments:
This research has been supported by Alexander von Humboldt Foundation. We greatly appreciate two anonymous reviewers for their constructive comments. We sincerely thank Mr. Hossein Maroufi for his generous help with the determination of plant specimens and providing access to the herbarium of Forests and Rangelands, Kurdistan Agricultural and Natural Resources Research and Education Center in Sanandaj. The article processing fee was covered by the open-access fund of University of Kassel.
\end{abstract}

\section{Data Availability:}

The vegetation and environmental data that support the findings of this study are available on request from the corresponding author (shakeri.zahed@gmail.com). None of the data are publicly available because of their containing information that could compromise endangered plant species. Our research did not target human subjects, and therefore formal approval was not required from our institution.

\section{LITERATURE CITED}

Abbasi, L., Z. Shakeri, N. Shabanian, and G. Moreno. 2017. Branch and leaf biomass of Lebanon oak (Quercus libani Oliv.) and Gall oak ( $Q$. infectoria Oliv.) trees in different years after pollarding [Title translated from the Persian by the authors]. Iranian Journal of Forest and Poplar Research 25:35-46.

Allendorf, T. D., J. S. Brandt, and J. M. Yang. 2014. Local perceptions of Tibetan village sacred forests in northwest
Yunnan. Biological Conservation 169:303-310. https://doi. org/10.1016/j.biocon.2013.12.001

Asri, Y. 2011. The flora of Iranian rangelands [Title translated from the Persian by the authors]. Research inistitude of Forests and Rangelands, Tehran, Iran.

Assadi, M., A. Ramak Maassoumi, and M. Khatamsaz. 1989. Flora of Iran. Ministry of Agriculture, Tehran, Iran.

Babaeian, E., H. Ghobari, and K. M. Samani. 2019. Redescription of Ololaelaps tasmanicus (Womersley, 1956) and description of a new species of Ololaelaps Berlese (Acari: Laelapidae) from Iran. Zootaxa 4629:351-364. https://doi. org/10.11646/zootaxa.4629.3.3

Baselga, A., and C. D. L. Orme. 2012. betapart: An R package for the study of beta diversity. Methods in Ecology and Evolution 3:808-812. https://doi.org/10.1111/j.2041-210X.2012.00224.X

Bhagwat, S. A., N. Dudley, and S. R. Harrop. 2011. Religious following in biodiversity hotspots: challenges and opportunities for conservation and development. Conservation Letters 4:234-240. https://doi.org/10.1111/j.1755-263X.2011.00169.x

Bhagwat, S. A., and C. Rutte. 2006. Sacred groves: potential for biodiversity management. Frontiers in Ecology and the Environment 4:519-524. https://doi.org/10.1890/1540-9295(2006) 4[519:SGPFBM]2.0.CO;2

Bouahim, S., L. Rhazi, B. Amami, N. Sahib, M. Rhazi, A. Waterkeyn, A. Zouahri, F. Mesleard, S. D. Muller, and P. Grillas. 2010. Impact of grazing on the species richness of plant communities in Mediterranean temporary pools (western Morocco). Comptes Rendus Biologies 333:670-679. https://doi. org/10.1016/j.crvi.2010.06.004

Cardelús, C. L., P. Scull, J. Hair, M. Baimas-George, M. D. Lowman, and A. W. Eshete. 2013. A preliminary assessment of Ethiopian sacred grove status at the landscape and ecosystem scales. Diversity 5:320-334. https://doi.org/10.3390/d5020320

Córdova, S. C., D. C. Olk, R. N. Dietzel, K. E. Mueller, S. V. Archontouilis, and M. J. Castellano. 2018. Plant litter quality affects the accumulation rate, composition, and stability of mineral-associated soil organic matter. Soil Biology and Biochemistry 125:115-124. https://doi.org/10.1016/j.soilbio.2018.07.010

Dafni, A. 2007. Rituals, ceremonies and customs related to sacred trees with a special reference to the Middle East. Journal of Ethnobiology and Ethnomedicine 3:28. https://doi. org/10.1186/1746-4269-3-28

Daniel, A. J., K. Potter, W. Altom, H. Aljoe, and R. Stevens. 2002. Long-term grazing density impacts on soil compaction. Transactions of the ASAE 45:1911-1915. https://doi. org/10.13031/2013.11442

Darvishsefat, A. A. 2006. Atlas of protected areas of Iran [Title translated from the Persian by the authors]. Department of Environment, Tehran, Iran.

Deil, U., H. Culmsee, and M. Berriane. 2005. Sacred groves in Morocco: a society's conservation of nature for spiritual reasons. Silva Carelica 49:185-201. 
Deil, U., A. Mhamdi, and B. El Fasskaoui. 2014. Les sites maraboutiques - un patrimoine naturel et culturel du Maroc (Maraboutic sites - a natural and cultural heritage from Moroco). Pages 171-178 in A. Kagermeier and B. Elfasskaoui, editors. Patrimoine et tourisme culturel au Maroc. Actes du 9ème colloque marocain-allemand de Meknès. University of Moulay Ismail, Meknes, Morocco.

Dudley, N., S. Bhagwat, L. Higgins-Zogib, B. Lassen, B. Verschuuren, and R. Wild. 2010. Conservation of biodiversity in sacred natural sites in Asia and Africa: a review of the scientific literature. Pages 19-32 in B. Verschuuren, R. Wild, J. McNeely, and G. Oviedo, editors. Sacred natural sites. Earthscan, London, UK.

Dudley, N., L. Higgins-Zogib, and S. Mansourian. 2009. The links between protected areas, faiths, and sacred natural sites. Conservation Biology 23:568-577. https://doi.org/10.1111/ j.1523-1739.2009.01201.x

Frascaroli, F., S. Bhagwat, R. Guarino, A. Chiarucci, and B. Schmid. 2016. Shrines in Central Italy conserve plant diversity and large trees. Ambio 45:468-479. https://doi.org/10.1007/ $\underline{\text { s13280-015-0738-5 }}$

Frascaroli, F., and B. Verschuuren. 2016. Linking biocultural diversity and sacred sites: evidence and recommendations in the European framework. Pages 389-417 in M. Agnoletti and F. Emanueli, editors. Biocultural diversity in Europe. Springer, Cham, Switzerland. https://doi.org/10.1007/978-3-319-26315-1_21

Fritsch, R. M., and N. Friesen. 2002. Evolution, domestication and taxonomy. Pages 5-30 in H. D. Rabinowitch and L. Currah, editors. Allium crop science: recent advances. CABI, Wallingford, UK. https://doi.org/10.1079/9780851995106.0005

Gaderzadeh, S., Z. Shakeri, V. Hosseini, and H. Maroufi. 2015. Determination of environmental factors affecting the distribution of plant species in northern Zagros forests (Case study: Armardeh Forest, Baneh). Iranian Journal of Forest Research 7:299-315.

Ghahramany, L., Z. Shakeri, E. Ghalavand, and H. Ghazanfari. 2017. Does diameter increment of Lebanon oak trees (Quercus libani Oliv.) affected by pollarding in Northern Zagros, Iran? Agroforestry Systems 91:741-748. https://doi.org/10.1007/ $\underline{\text { 10457-016-9944-9 }}$

Ghazanfari, H., M. Namiranian, H. Sobhani, and R. M. Mohajer. 2004. Traditional forest management and its application to encourage public participation for sustainable forest management in the northern Zagros Mountains of Kurdistan Province, Iran. Scandinavian Journal of Forest Research 19:65-71. https://doi.org/10.1080/14004080410034074

Hartel, T., and T. Plieninger. 2014. European wood-pastures in transition: a social-ecological approach. Routledge, London, UK. https://doi.org/10.4324/9780203797082

Isichei, A. O., and J. I. Muoghalu. 1992. The effects of tree canopy cover on soil fertility in a Nigerian savanna. Journal of Tropical Ecology 8:329-338. https://doi.org/10.1017/S0266467400006623

Izady, M. 1994. Are Kurds descended from the Medes? Kurdish Life 10:8-10.
Jäckle, H., M. Rudner, and U. Deil. 2013. Density, spatial pattern and relief features of sacred sites in Northern Morocco. Landscape Online 32:1-16. https://doi.org/10.3097/LO.201332

Jalili, A., and Z. Jamzad. 1999. Red data book of Iran: a preliminary survey of endemic, rare \& endangered plant species in Iran [Title translated from the Persian by the authors]. Research Institute of Forests and Rangelands, Ministry of Jahad-e Sazandegi Tech, Tehran, Iran.

James, E., P. Kleinman, T. Veith, R. Stedman, and A. Sharpley. 2007. Phosphorus contributions from pastured dairy cattle to streams of the Cannonsville Watershed, New York. Journal of Soil and Water Conservation 62:40-47.

Khajoei Nasab, F., and A. R. Khosravi. 2014. Ethnobotanical study of medicinal plants of Sirjan in Kerman Province, Iran. Journal of Ethnopharmacology 154:190-197. https://doi. org/10.1016/j.jep.2014.04.003

Khezri, S. 2002. The culture of Kurdistan medicinal plants [Title translated from the Persian by the authors]. University of Kurdistan, Sanandaj, Iran.

Legendre, P., and L. F. Legendre. 2012. Numerical ecology. Elsevier, Amsterdam, The Netherlands.

Löki, V., J. Tökölyi, K. Süveges, Á. Lovas-Kiss, K. Hürkan, G. Sramkó, and A. Molnár. 2015. The orchid flora of Turkish graveyards: a comprehensive field survey. Willdenowia 45:231-243. https://doi.org/10.3372/wi.45.45209

Londo, G. 1976. The decimal scale for releves of permanent quadrats. Vegetatio 33:61-64. https://doi.org/10.1007/BF00055300

Maroufi, H. 2010. Two new plant species from Kurdistan province, West of Iran. Iranian Journal of Botany 16:76-80.

Mashayekhi, S., S. Zarre, R. Fritsch, and F. Attar. 2005. A new species of Allium subgen. Melanocrommyum sect. Compactoprason (Alliaceae) from Iran. Feddes Repertorium 116:191-194. https:// doi.org/10.1002/fedr.200411065

Mgumia, F. H., and G. Oba. 2003. Potential role of sacred groves in biodiversity conservation in Tanzania. Environmental Conservation 30:259-265. https://doi.org/10.1017/S0376892903000250

Mohammadi Samani, K., N. Pordel, V. Hosseini, and Z. Shakeri. 2020. Effect of land-use changes on chemical and physical properties of soil in western Iran (Zagros oak forests). Journal of Forestry Research 31:637-647. https://doi.org/10.1007/s11676-018-0799$\mathrm{y}$

Morony, M. 2019. Arab ii. Arab conquest of Iran. The encyclopedia Iranica. Center for Iranian Studies, Columbia University, New York, New York, USA. [online] URL: http://www.iranicaonline. org/articles/arab-ii

Müller-Dombois, D., and H. Ellenberg. 2002. Aims and methods of vegetation ecology. Second edition. Blackburn, Caldwell, New Jersey, USA.

Oksanen, J., F. G. Blanchet, R. Kindt, P. Legendre, R. O’Hara, G. L. Simpson, P. Solymos, M. H. H. Stevens, and H. Wagner. 2010. Vegan: community ecology package. $\mathrm{R}$ package version 1.17-4. [online] URL: http://CRAN.R-project.org/package= vegan 
Orefice, J., R. G. Smith, J. Carroll, H. Asbjornsen, and D. Kelting. 2017. Soil and understory plant dynamics during conversion of forest to silvopasture, open pasture, and woodlot. Agroforestry Systems 91:729-739. https://doi.org/10.1007/s10457-016-0040-y

Ormsby, A. A., and S. A. Bhagwat. 2010. Sacred forests of India: a strong tradition of community-based natural resource management. Environmental Conservation 37:320-326. https:// doi.org/10.1017/S0376892910000561

Paktinat-Saeij, S., H. Ghobari, and K. M. Samani. 2020. First new species of the Caeculidae (Acari: Trombidiformes: Prostigmata) from Iran, with a key to the world species of Allocaeculus. Systematic and Applied Acarology 25:833-842. https://doi.org/10.11158/saa.25.5.5

Papanikolaou, A. D., N. M. Fyllas, A. D. Mazaris, P. G. Dimitrakopoulos, A. S. Kallimanis, and J. D. Pantis. 2011. Grazing effects on plant functional group diversity in Mediterranean shrublands. Biodiversity and Conservation 20:2831. https://doi.org/10.1007/s10531-011-0112-2

Pärtel, M. 2014. Community ecology of absent species: hidden and dark diversity. Journal of Vegetation Science 25:1154-1159. https://doi.org/10.1111/jvs. 12169

Plieninger, T., C. Quintas-Soriano, M. Torralba, K. Mohammadi Samani, and Z. Shakeri. 2020. Social dynamics of values, taboos and perceived threats around sacred groves in Kurdistan, Iran. People and Nature 2:1237-1250. https://doi.org/10.1002/ pan3.10158

R Core Team. 2019. R: A language and environment for statistical computing. [online] URL: https://www.r-project.org/

Ray, R., and T. Ramachandra. 2010. Small sacred groves in local landscape: are they really worthy for conservation? Current Science 98:1178-1180.

Roohi, M. 2014. Breaking down the historical problems in Iranian Kurdish territories [Title translated from the Persian by the authors]. Journal of Iranian Sociology 4:63-93.

Sadeghi, M., M. Malekian, and L. Khodakarami. 2017. Forest losses and gains in Kurdistan province, western Iran: Where do we stand? Egyptian Journal of Remote Sensing and Space Science 20:51-59. https://doi.org/10.1016/j.ejrs.2016.07.001

Schulz, K., K. Voigt, C. Beusch, J. S. Almeida-Cortez, I. Kowarik, A. Walz, and A. Cierjacks. 2016. Grazing deteriorates the soil carbon stocks of Caatinga forest ecosystems in Brazil. Forest Ecology and Management 367:62-70. https://doi.org/10.1016/j. foreco.2016.02.011

Shakeri, Z. 2006. Ecological and silvicultural effects of Galazani in Northern Zagros oak forests [In Persian with English summary]. Thesis. University of Tehran, Karaj, Iran.

Shakeri, Z., M. R. Marvi Mohajer, M. Namiraninan, and V. Etemad. 2009. Comparison of seedling and coppice regeneration in pruned and undisturbed oak forests of Northern Zagros (Case study: Baneh, Kurdistan province) [In Persian with English summary]. Iranian Journal of Forest and Poplar Research 17:84-73.

Shakeri, Z., and M. Mostafa. 2018. Spatial distribution of lessdisturbed forest stands in Baneh. Pages 1-7 in A. Molaii, editor.
The 3rd national congress on energy, environment, agriculture and sustainable development [In Persian with English summary]. Azad University, Snandaj, Iran.

Sharrow, S. H. 2007. Soil compaction by grazing livestock in silvopastures as evidenced by changes in soil physical properties. Agroforestry Systems 71:215-223. https://doi.org/10.1007/ s10457-007-9083-4

Singh, J. S., and S. R. Gupta. 1977. Plant decomposition and soil respiration in terrestrial ecosystems. Botanical Review 43:449-528. https://doi.org/10.1007/BF02860844

Townsend, C., and E. Guest. 1974. Flora of Iraq. Bentham-Moxon Trust, London, UK.

Valipour, A., T. Plieninger, Z. Shakeri, H. Ghazanfari, M. Namiranian, and M. J. Lexer. 2014. Traditional silvopastoral management and its effects on forest stand structure in northern Zagros, Iran. Forest Ecology and Management 327:221-230. https://doi.org/10.1016/j.foreco.2014.05.004

Verschuuren, B., and N. Furuta. 2016. Asian sacred natural sites: philosophy and practice in protected areas and conservation. Routledge, London, UK. https://doi.org/10.4324/9781315676272

Wardle, D. A., G. W. Yeates, G. M. Barker, and K. I. Bonner. 2006. The influence of plant litter diversity on decomposer abundance and diversity. Soil Biology and Biochemistry 38:1052-1062. https:// doi.org/10.1016/j.soilbio.2005.09.003

Watson, D. M., H. W. McGregor, and P. G. Spooner. 2011. Hemiparasitic shrubs increase resource availability and multitrophic diversity of eucalypt forest birds. Functional Ecology 25:889-899. https://doi.org/10.1111/j.1365-2435.2011.01839.x

White, L. 1967. The historical roots of our ecologic crisis. Science 155:1203-1207. https://doi.org/10.1126/science.155.3767.1203

Wild, R., C. McLeod, and P. Valentine. 2008. Sacred natural sites: guidelines for protected area managers. IUCN, Gland, Switzerland.

Willis, A. J. 2001. Endangered plants in Iran. New Phytologist 149:165-165. https://doi.org/10.1046/j.1469-8137.2001.00043-3.x

Young, F. W. 2013. Multidimensional scaling: history, theory, and applications. Psychology Press, Hove, UK.

Zohary, M. 1963. On the geobotanical structure of Iran. Weisman Science Press, Jerusalem, Israel. 


\section{Appendix 1}

Title: Spiritual values shape taxonomic diversity, vegetation composition, and conservation status in woodlands of the Northern Zagros, Iran

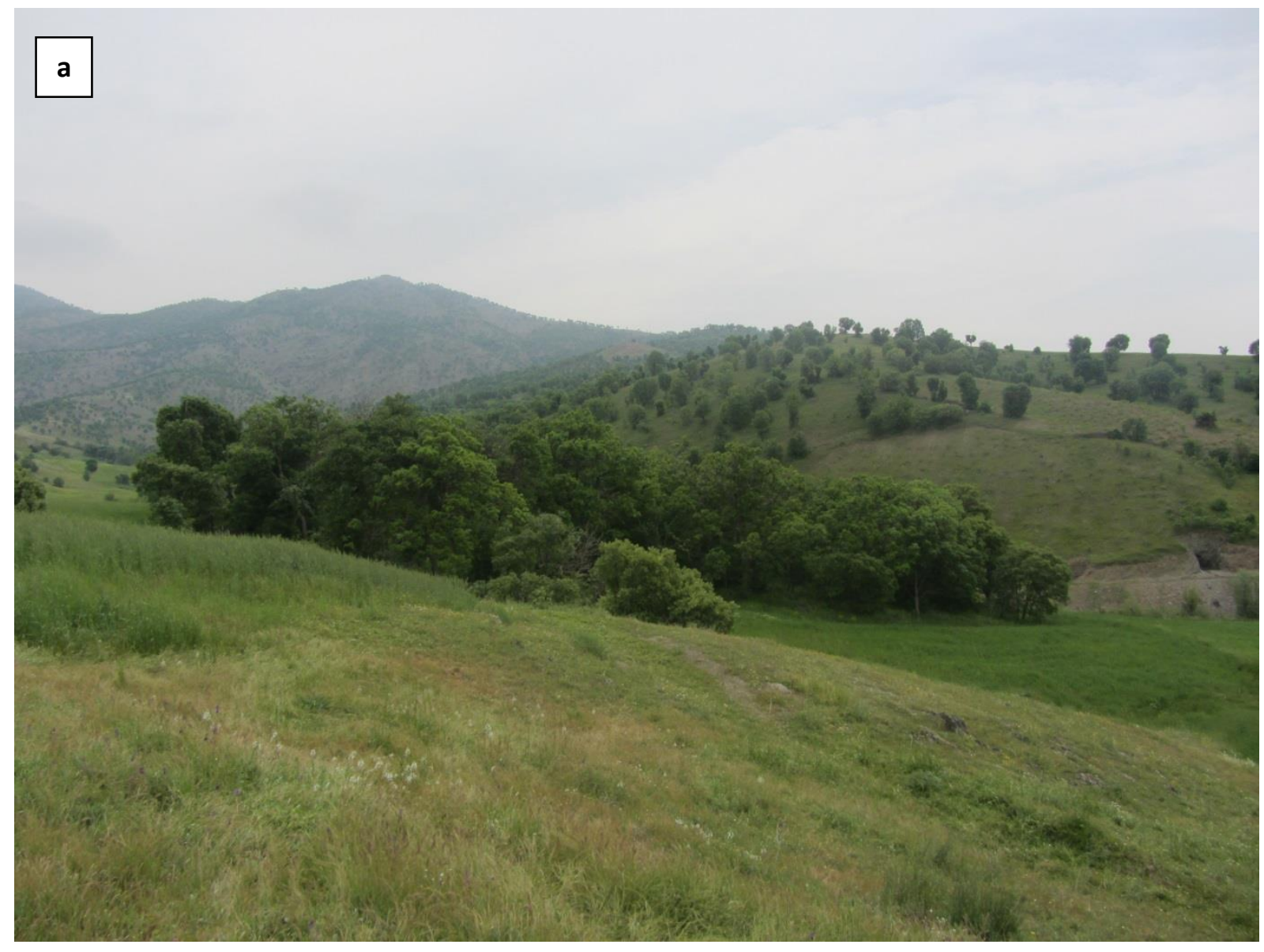




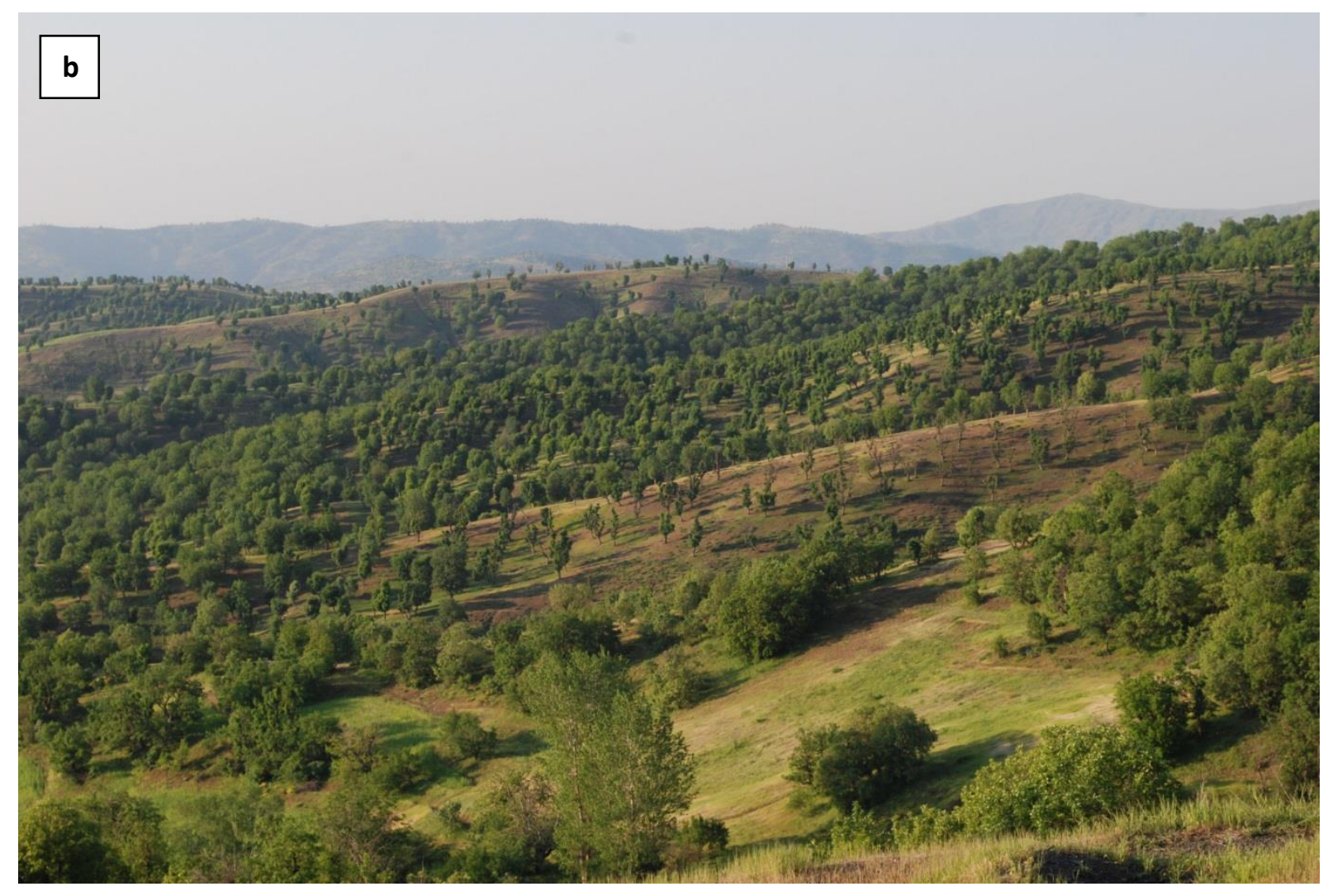

Figure A1.1: (a) A sacred grove surrounded by traditional farmland and woodland and (b) Silvopastoral woodland of traditionally pollarded oaks. 


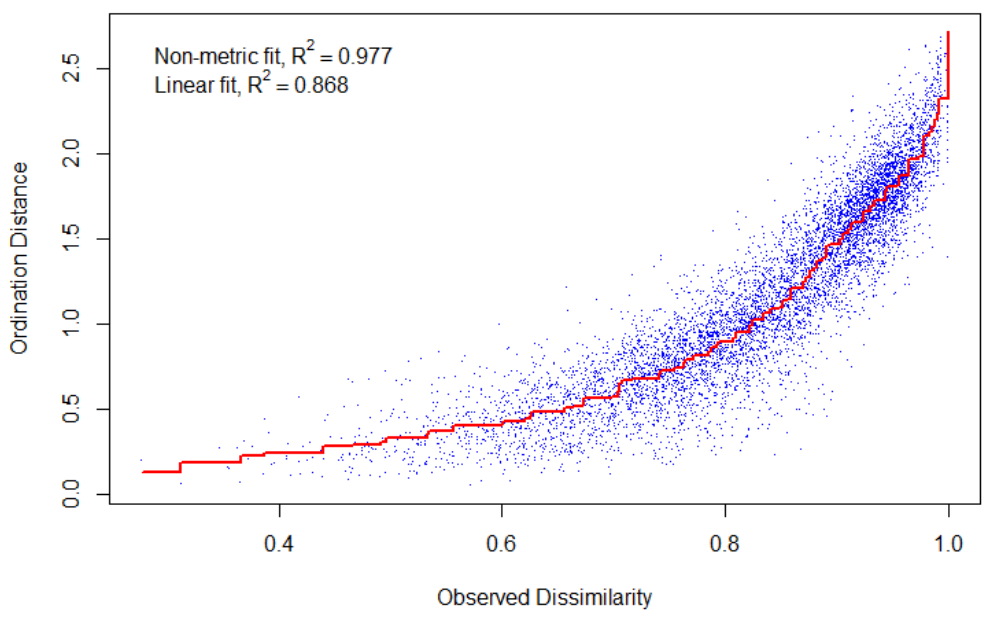

Figure A1.2: Shepard diagram resulted from non-metric multidimensional scaling analysis to plot the ordination distance and linear fit line of vegetation data against the original dissimilarities. 


\section{Appendix 2}

Title: Spiritual values shape taxonomic diversity, vegetation composition, and conservation status in woodlands of the Northern Zagros, Iran

Table A2.1: Plant species found in sacred groves (SG) and surrounding woodlands (SW) of Baneh area. Scientific names follow the International Plant Name Index (https://www.ipni.org/). Common plant names in English are given, if appropriate, at species or genus level. Abbreviations for life form: Ch, Chamaephyte; $\mathrm{Cr}$, cryptophyte; $\mathrm{He}$, hemicryptophyte; $\mathrm{Ph}$, phanerophyte; and Th, therophyte. Conservation status of species evaluated based on IUCN categories at national level (Jalili and Jamzad 1999). Abbreviations for IUCN plant categories: CR, critically endangered; DD, data deficient; EN, endangered; LC, least concern; NE, not evaluated; NT, near threatened; and VU, vulnerable. Constancy classes (I: 0-20\%, II: 21-40\%, III: 41-60\%, IV: 61-80\%, and V: 81-100\%) provided for each species at all sites (All), sacred groves (SG), and surrounding woodlands (SW) respectively.

\begin{tabular}{|c|c|c|c|c|c|c|c|}
\hline \multirow{2}{*}{ Family } & \multirow[t]{2}{*}{ Scientific name } & \multirow[t]{2}{*}{$\begin{array}{c}\text { Common English } \\
\text { name }\end{array}$} & \multirow{2}{*}{$\begin{array}{l}\text { Life } \\
\text { form }\end{array}$} & \multirow{2}{*}{$\begin{array}{l}\text { Conservation } \\
\text { status }\end{array}$} & \multicolumn{3}{|c|}{$\begin{array}{l}\text { Constancy } \\
\text { classes }\end{array}$} \\
\hline & & & & & All & SG & SW \\
\hline Acanthaceae & Acanthus dioscoridis L. & $\begin{array}{l}\text { Dioscorides' } \\
\text { Bear's-breech }\end{array}$ & $\mathrm{He}$ & NT & 1 & 1 & 1 \\
\hline Aceraceae & Acer monspessulanum $\mathrm{L}$. & $\begin{array}{l}\text { Montpellier } \\
\text { maple }\end{array}$ & $\mathrm{Ph}$ & VU & I & 1 & 1 \\
\hline \multirow[t]{7}{*}{ Amaryllidaceae } & Allium atroviolaceum Boiss. & $\begin{array}{l}\text { Broadleaved } \\
\text { wild leek }\end{array}$ & $\mathrm{Cr}$ & VU & 1 & I & 1 \\
\hline & Allium eriophyllum Boiss. & Wild garlic & $\mathrm{Cr}$ & NE & 1 & 1 & 0 \\
\hline & $\begin{array}{l}\text { Allium hooshidaryae Mashayekhi, Zarre } \\
\text { \& R.M.Fritsch }\end{array}$ & Wild garlic & $\mathrm{Cr}$ & CR & 1 & I & 0 \\
\hline & Allium jesdianum Boiss.\& Buhse & Wild garlic & $\mathrm{Cr}$ & VU & 1 & 1 & 0 \\
\hline & $\begin{array}{l}\text { Allium macrochaetum Boiss. \& } \\
\text { Hausskn. ex Boiss. }\end{array}$ & Wild garlic & $\mathrm{Cr}$ & NT & 1 & II & 1 \\
\hline & Allium saralicum R.M. Fritsch & Wild garlic & $\mathrm{Cr}$ & CR & I & I & 0 \\
\hline & Allium stamineum Boiss. & Wild garlic & $\mathrm{Cr}$ & VU & I & 0 & 1 \\
\hline Anacardiaceae & Pistacia atlantica Desf. & $\begin{array}{l}\text { Persian } \\
\text { turpentine tree }\end{array}$ & $\mathrm{Ph}$ & NT & 1 & 1 & 1 \\
\hline \multirow[t]{9}{*}{ Apiaceae } & Bunium elegans (Fenzl) Freyn & Pignut & $\mathrm{He}$ & NE & III & III & III \\
\hline & Chaerophyllum aureum L. & Golden chervil & $\mathrm{He}$ & NT & I & III & 1 \\
\hline & Chaerophyllum macropodum Boiss. & Chervil & $\mathrm{He}$ & NT & 1 & 1 & 1 \\
\hline & $\begin{array}{l}\text { Chaerophyllum macrospermum (Willd. } \\
\text { ex Schult.) Fisch. \& C.A.Mey. }\end{array}$ & Chervil & $\mathrm{Cr}$ & NT & I & 1 & 0 \\
\hline & Falcaria vulgaris Bernh. & Longleaf & $\mathrm{He}$ & NT & I & 1 & 0 \\
\hline & Grammosciadium scabridum Boiss. & - & Th & NE & I & 1 & 1 \\
\hline & $\begin{array}{l}\text { Grammosciadium platycarpum Boiss. \& } \\
\text { Hausskn. ex Boiss. }\end{array}$ & - & $\mathrm{He}$ & NE & 1 & 1 & 0 \\
\hline & Heptaptera anatolica (Boiss.) Tutin & - & $\mathrm{He}$ & NE & 1 & III & 0 \\
\hline & Heracleum persicum Desf. ex Fisch., & Persian & $\mathrm{He}$ & NT & 1 & I & 0 \\
\hline
\end{tabular}




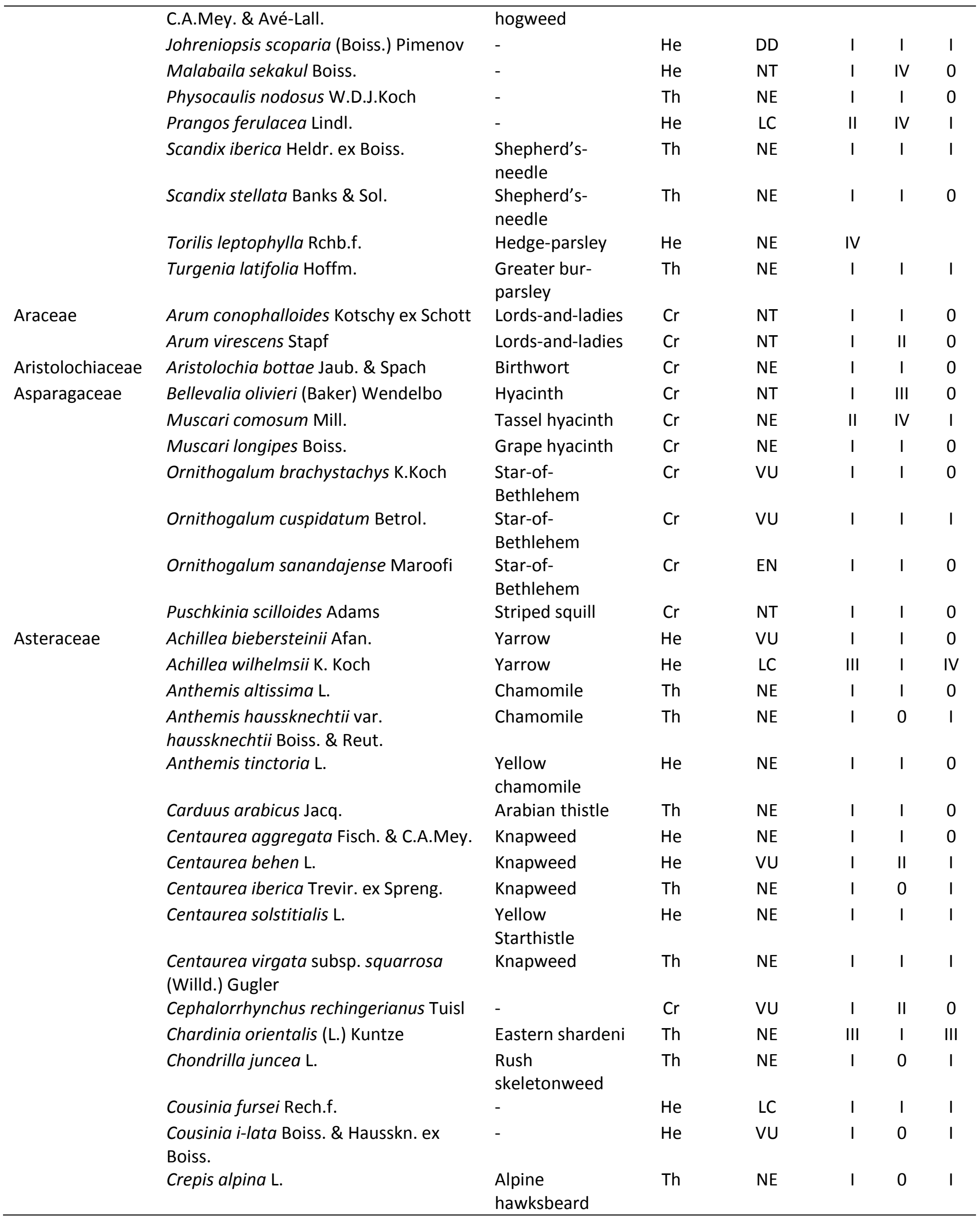




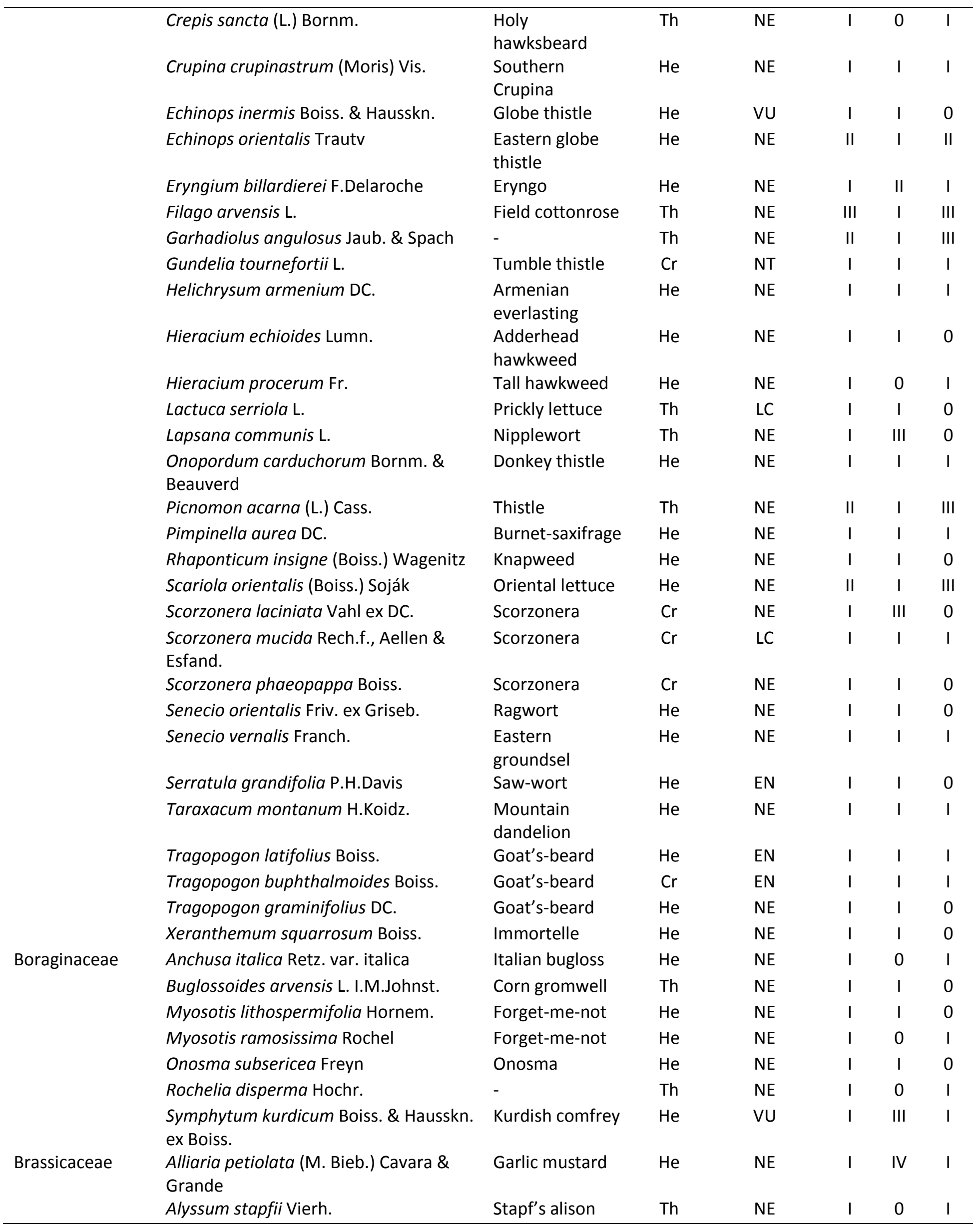




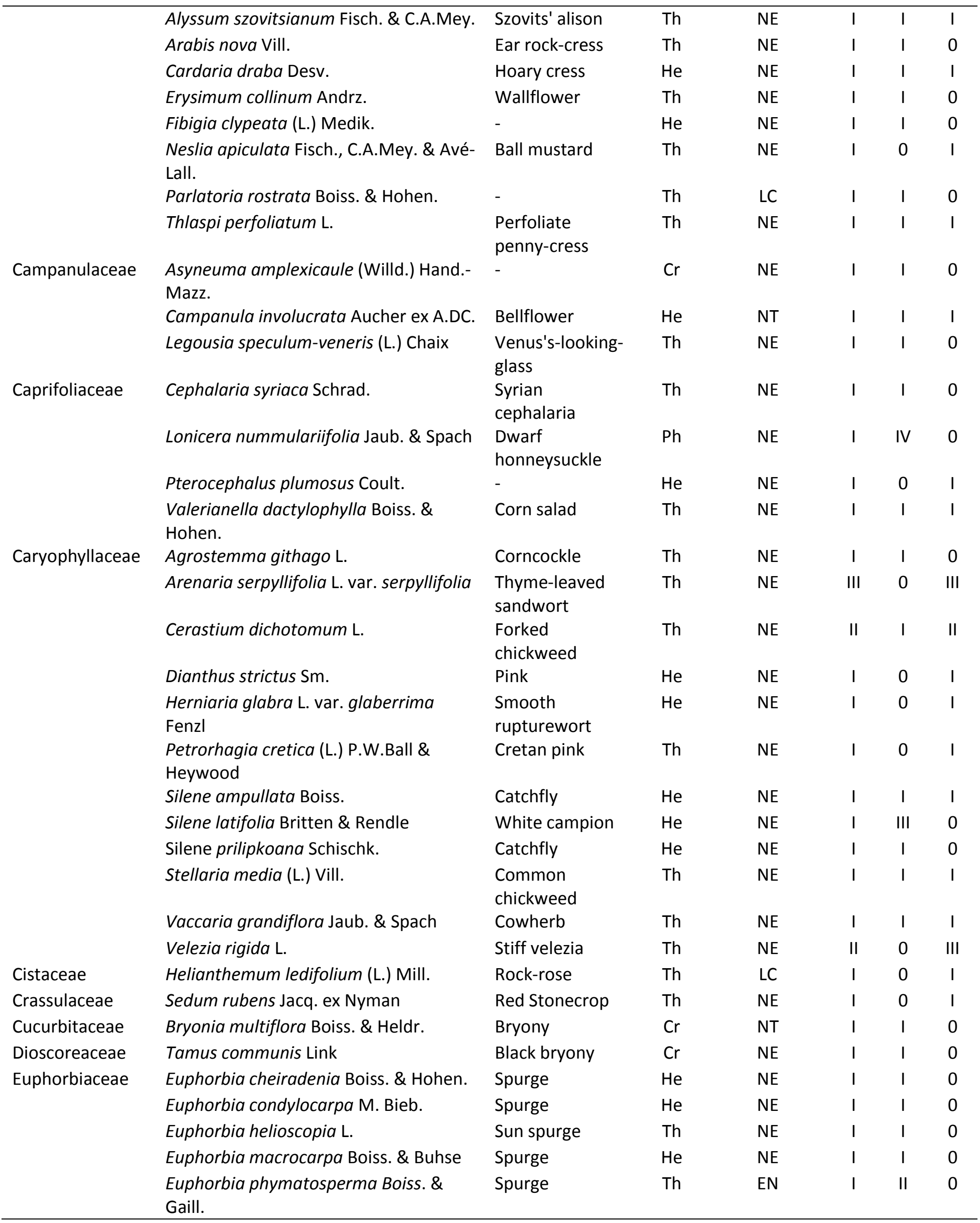




\begin{tabular}{|c|c|c|c|c|c|c|c|}
\hline \multirow[t]{32}{*}{ Fabaceae } & Astragalus caryolobus Bunge & Milkvetch & $\mathrm{He}$ & NT & 1 & I & 0 \\
\hline & Astragalus curvirostris Boiss. & Milkvetch & $\mathrm{He}$ & LC & I & I & I \\
\hline & Astragalus echinops Boiss. & Milkvetch & $\mathrm{He}$ & LC & I & I & 0 \\
\hline & Astragalus gossypinus Fisch. & Milkvetch & $\mathrm{He}$ & LC & II & II & II \\
\hline & Astragalus michauxianus Boiss. & Milkvetch & $\mathrm{He}$ & LC & ॥ & I & ॥ \\
\hline & Astragalus ovinus Boiss. & Milkvetch & $\mathrm{He}$ & LC & 1 & I & I \\
\hline & $\begin{array}{l}\text { Astragalus piranshahricus Maassoumi } \\
\text { \& Podlech }\end{array}$ & Milkvetch & $\mathrm{Ch}$ & VU & I & I & 0 \\
\hline & Astragalus sp. & Milkvetch & $\mathrm{He}$ & $\mathrm{NE}$ & 1 & I & I \\
\hline & Astragalus tortuosus DC. & Milkvetch & $\mathrm{He}$ & LC & 1 & I & I \\
\hline & Astragalus verus Olivier & Milkvetch & $\mathrm{He}$ & LC & 1 & 0 & I \\
\hline & Cicer oxyodon Boiss. \& Hohen. & Wild chickpea & Th & VU & 1 & I & 0 \\
\hline & Coronilla varia $\mathrm{L}$. & Crown vetch & $\mathrm{He}$ & $\mathrm{NE}$ & I & I & 0 \\
\hline & Lathyrus aphaca L. & Yellow vetchling & Th & NT & I & I & 0 \\
\hline & $\begin{array}{l}\text { Lathyrus inconspicuus L. var. } \\
\text { inconspicuus }\end{array}$ & $\begin{array}{l}\text { Inconspicuous } \\
\text { vetchling }\end{array}$ & Th & NT & 1 & 0 & II \\
\hline & Lathyrus rotundifolius Willd. & $\begin{array}{l}\text { Persian } \\
\text { everlasting pea }\end{array}$ & Th & VU & I & I & 0 \\
\hline & $\begin{array}{l}\text { Lens orientalis subsp. orientalis (Boiss.) } \\
\text { Ponert }\end{array}$ & Eastern lentil & Th & NE & I & 0 & I \\
\hline & Lotus corniculatus var. corniculatus L. & $\begin{array}{l}\text { Common bird's- } \\
\text { foot-trefoil }\end{array}$ & Th & NE & I & I & I \\
\hline & Lotus gebelia Var. gebelia Vent. & $\begin{array}{l}\text { Bird's-foot- } \\
\text { trefoil }\end{array}$ & $\mathrm{He}$ & NE & I & I & I \\
\hline & Medicago sativa $\mathrm{L}$. & Alfalfa, Lucerne & $\mathrm{He}$ & $\mathrm{NE}$ & I & I & 0 \\
\hline & Pisum sativum L. & Garden pea & Th & NE & I & I & 0 \\
\hline & Trifolium campestre C.C.Gmel. & Hop trefoil & Th & NE & I & 1 & I \\
\hline & Trifolium dasyurum C.Presl & $\begin{array}{l}\text { Eastern starry } \\
\text { clover }\end{array}$ & Th & $\mathrm{NE}$ & I & I & 0 \\
\hline & Trifolium pilulare Boiss. & $\begin{array}{l}\text { Ball cotton } \\
\text { clover }\end{array}$ & Th & LC & I & 0 & I \\
\hline & Trifolium pratense $\mathrm{L}$. & Red clover & $\mathrm{He}$ & NE & I & I & 0 \\
\hline & $\begin{array}{l}\text { Trifolium purpureum Gueldenst. ex } \\
\text { Ledeb. }\end{array}$ & Purple clover & Th & $\mathrm{NE}$ & II & 0 & III \\
\hline & Trifolium repens Walter & White clover & $\mathrm{He}$ & $\mathrm{NE}$ & I & II & 0 \\
\hline & Trifolium spumosum L. & $\begin{array}{l}\text { Mediterranean } \\
\text { clover }\end{array}$ & Th & $\mathrm{DD}$ & I & 1 & I \\
\hline & Vicia michauxii Schrank ex Steud. & Michaux' tare & Th & $\mathrm{NE}$ & I & I & I \\
\hline & Vicia narbonensis L. & Narbonne vetch & Th & $\mathrm{NE}$ & I & II & I \\
\hline & Vicia sativa subsp. sativa $\mathrm{L}$. & Common vetch & Th & $\mathrm{NE}$ & I & II & 0 \\
\hline & Vicia sericocarpa Fenzl & Vetch & Th & LC & I & 1 & I \\
\hline & Vicia variabilis Freyn \& Sint. ex Freyn & Vetch & Th & NE & II & III & I \\
\hline \multirow[t]{3}{*}{ Fagaceae } & Quercus brantii Lindl. & Brant's oak & $\mathrm{Ph}$ & NT & III & IV & ॥ \\
\hline & Quercus i-ectoria Oliv. & Aleppo oak & $\mathrm{Ph}$ & LC & V & V & V \\
\hline & Quercus libani Oliv. & Lebanon oak & $\mathrm{Ph}$ & LC & IV & IV & IV \\
\hline Gentianaceae & Gentiana olivieri Griseb. & Olivier's gentian & $\mathrm{Cr}$ & $\mathrm{NE}$ & I & I & I \\
\hline \multirow[t]{2}{*}{ Geraniaceae } & Geranium sp. & Crane's-bill & $\mathrm{Cr}$ & NE & I & I & 1 \\
\hline & Geranium tuberosum L. & $\begin{array}{l}\text { Tuberous } \\
\text { crane's-bill }\end{array}$ & $\mathrm{Cr}$ & $\mathrm{NE}$ & I & III & I \\
\hline
\end{tabular}




\begin{tabular}{|c|c|c|c|c|c|c|c|}
\hline \multirow[t]{3}{*}{ Hypericaceae } & Hypericum asperulum Jaub. \& Spach & St John's-wort & $\mathrm{Cr}$ & $\mathrm{LC}$ & 1 & 1 & 1 \\
\hline & Hypericum lysimachioides Boiss. \& Noë & St John's-wort & $\mathrm{Ch}$ & $\mathrm{LC}$ & I & 1 & 0 \\
\hline & Hypericum scabrum L. & $\begin{array}{l}\text { Scabrous St } \\
\text { John's-wort }\end{array}$ & $\mathrm{He}$ & LC & I & 0 & I \\
\hline Iridaceae & Iris reticulata M.Bieb. & Netted iris & $\mathrm{Cr}$ & $\mathrm{LC}$ & I & I & I \\
\hline Ixioliriaceae & $\begin{array}{l}\text { Ixiolirion tataricum (Pall.) Herb. \& } \\
\text { Traub }\end{array}$ & $\begin{array}{l}\text { Lavender } \\
\text { mountain-lily }\end{array}$ & $\mathrm{Cr}$ & LC & I & 1 & I \\
\hline \multirow[t]{12}{*}{ Lamiaceae } & Lallemantia iberica Fisch. \& C.A.Mey. & Dragon's head & Th & $\mathrm{NE}$ & I & I & 0 \\
\hline & Lamium album subsp. Album L. & $\begin{array}{l}\text { White dead- } \\
\text { nettle }\end{array}$ & $\mathrm{He}$ & $\mathrm{NE}$ & II & II & II \\
\hline & $\begin{array}{l}\text { Lamium amplexicaule var. amplexicaule } \\
\text { L. }\end{array}$ & $\begin{array}{l}\text { Henbit dead- } \\
\text { nettle }\end{array}$ & Th & $\mathrm{NE}$ & 1 & 1 & I \\
\hline & Marrubium astracanicum Jacq. & $\begin{array}{l}\text { Astrakhan } \\
\text { horehound }\end{array}$ & $\mathrm{He}$ & NE & 1 & 0 & I \\
\hline & Marrubium cuneatum Banks \& Sol. & $\begin{array}{l}\text { Cuneate } \\
\text { horehound }\end{array}$ & $\mathrm{Cr}$ & $\mathrm{NE}$ & I & 0 & I \\
\hline & Nepeta sintenisii Bornm. & Catnip & $\mathrm{He}$ & $\mathrm{NE}$ & 1 & 1 & 0 \\
\hline & Phlomis persica Boiss. & $\begin{array}{l}\text { Persian } \\
\text { Jerusalem sage }\end{array}$ & $\mathrm{He}$ & $\mathrm{LC}$ & II & I & II \\
\hline & Salvia atropatana Bunge & Atropatene sage & $\mathrm{He}$ & $\mathrm{NE}$ & I & 1 & 0 \\
\hline & Salvia bracteata Sims & Bracteate sage & $\mathrm{He}$ & $\mathrm{NE}$ & I & IV & 0 \\
\hline & $\begin{array}{l}\text { Scutellaria condensata subsp. } \\
\text { pycnotricha Rech.f. }\end{array}$ & Skullcap & $\mathrm{He}$ & EN & I & 1 & 0 \\
\hline & Teucrium polium Decne. ex C.Presl & Felty germander & $\mathrm{Ch}$ & NE & 1 & 1 & I \\
\hline & Ziziphora capitata L. & Ziziphora & Th & $\mathrm{NE}$ & IV & 1 & V \\
\hline \multirow[t]{3}{*}{ Liliaceae } & Fritillaria imperialis L. & $\begin{array}{l}\text { Crown imperial } \\
\text { fritillary }\end{array}$ & $\mathrm{Cr}$ & NT & I & I & 0 \\
\hline & Fritillaria straussii Bornm. & Strauss' fritillary & $\mathrm{Cr}$ & EN & 1 & 1 & 0 \\
\hline & Tulipa systola Stapf & Desert tulip & $\mathrm{Cr}$ & NT & 1 & 1 & I \\
\hline \multirow[t]{2}{*}{ Malvaceae } & Alcea hohenackeri Boiss. & Hollyhock & $\mathrm{He}$ & $\mathrm{NE}$ & I & 0 & I \\
\hline & Alcea kurdica (Schltdl.) Alef. & $\begin{array}{l}\text { Kurdish } \\
\text { hollyhock }\end{array}$ & $\mathrm{He}$ & NT & I & 1 & 0 \\
\hline \multirow[t]{5}{*}{ Orchidaceae } & $\begin{array}{l}\text { Cephalanthera kurdica subsp. kurdica } \\
\text { (Bornm.) H.Sundermann. }\end{array}$ & $\begin{array}{l}\text { Kurdish } \\
\text { helleborine }\end{array}$ & $\mathrm{Cr}$ & NT & I & 1 & 0 \\
\hline & $\begin{array}{l}\text { Comperia comperiana (Steven) Asch. \& } \\
\text { Graebn. }\end{array}$ & Comperia & $\mathrm{Cr}$ & $\mathrm{NE}$ & I & II & 0 \\
\hline & Epipactis helleborine (L.) Crantz & $\begin{array}{l}\text { Broadleaved } \\
\text { helleborine }\end{array}$ & $\mathrm{Cr}$ & EN & I & II & I \\
\hline & $\begin{array}{l}\text { Ophrys reinholdii subspec. straussii } \\
\text { (H.Fleischm.) E.Nelson }\end{array}$ & $\begin{array}{l}\text { Reinhold's bee- } \\
\text { orchid }\end{array}$ & $\mathrm{Cr}$ & EN & 1 & 1 & 0 \\
\hline & $\begin{array}{l}\text { Ophrys sphegodes var. transhyrcana } \\
\text { (Czerniak.) P.J.Cribb }\end{array}$ & $\begin{array}{l}\text { Transhyrcanian } \\
\text { bee-orchid }\end{array}$ & $\mathrm{Cr}$ & EN & I & 1 & 0 \\
\hline \multirow[t]{3}{*}{ Orobanchaceae } & $\begin{array}{l}\text { Orobanche coelestis Boiss. \& Reut. ex } \\
\text { Reut. }\end{array}$ & Broomrape & Th & NE & 1 & 1 & 0 \\
\hline & Orobanche kochii F.W.Schultz & Broomrape & Th & $\mathrm{NE}$ & I & 1 & 0 \\
\hline & Rhynchocorys elephas (L.) Griseb. & - & Th & $\mathrm{NE}$ & I & 1 & 0 \\
\hline \multirow[t]{3}{*}{ Papaveraceae } & Fumaria vaillantii Loisel. & $\begin{array}{l}\text { Few-flowered } \\
\text { fumitory }\end{array}$ & Th & EN & I & 1 & 0 \\
\hline & Papaver bracteatum Lindl. & Poppy & $\mathrm{He}$ & $\mathrm{NE}$ & I & 1 & 0 \\
\hline & Papaver macrostomum subsp. & Poppy & Th & VU & 1 & I & 0 \\
\hline
\end{tabular}




\begin{tabular}{|c|c|c|c|c|c|c|c|}
\hline \multirow{5}{*}{ Plantaginaceae } & \multicolumn{7}{|l|}{ macrostomum Boiss. \& A. Huet } \\
\hline & Plantago lanceolata L. & Ribwort plantain & $\mathrm{He}$ & $\mathrm{NE}$ & I & I & I \\
\hline & Veronica bozakmanii M.A.Fisch. & Speedwell & Th & $\mathrm{NE}$ & I & 0 & II \\
\hline & Veronica campylopoda Boiss. & $\begin{array}{l}\text { Bent-stalked } \\
\text { speedwell }\end{array}$ & $\mathrm{He}$ & $\mathrm{NE}$ & II & I & II \\
\hline & Veronica orientalis Mill. & $\begin{array}{l}\text { Eastern } \\
\text { speedwell }\end{array}$ & $\mathrm{He}$ & $\mathrm{NE}$ & 1 & 1 & 0 \\
\hline \multirow[t]{16}{*}{ Poaceae } & Aegilops triuncialis $\mathrm{L}$. & $\begin{array}{l}\text { Barbed } \\
\text { goatgrass }\end{array}$ & Th & NE & II & 0 & III \\
\hline & Alopecurus pratensis L. & Meadow foxtail & $\mathrm{He}$ & $\mathrm{NE}$ & 1 & 0 & $\mathrm{I}$ \\
\hline & Avena sterilis $\mathrm{L}$. & Winter wild oat & Th & $\mathrm{NE}$ & I & I & 0 \\
\hline & $\begin{array}{l}\text { Bromus danthoniae var. danthoniae } \\
\text { Trin. ex C.A.Mey. }\end{array}$ & Oat brome & Th & $\mathrm{LC}$ & IV & 1 & V \\
\hline & Bromus sterilis L. & Barren brome & Th & $\mathrm{LC}$ & 1 & IV & I \\
\hline & Bromus tectorum $\mathrm{L}$. & Drooping brome & Th & $\mathrm{LC}$ & III & 0 & IV \\
\hline & Dactylis glomerata L. & Orchard grass & $\mathrm{He}$ & $\mathrm{NE}$ & 1 & III & I \\
\hline & Elymus panormitanus (Bertol.) Tzvelev & $\begin{array}{l}\text { Woodland couch } \\
\text { grass }\end{array}$ & Th & NT & 1 & II & I \\
\hline & $\begin{array}{l}\text { Eremopoa persica var. persica (Trin.) } \\
\text { Roshev. }\end{array}$ & $\begin{array}{l}\text { Persian } \\
\text { hermitage }\end{array}$ & Th & VU & II & 0 & II \\
\hline & $\begin{array}{l}\text { Heteranthelium piliferum Hochst. ex } \\
\text { Jaub. \& Spach }\end{array}$ & - & Th & $\mathrm{NE}$ & III & I & IV \\
\hline & Hordeum bulbosum L. & Bulbous barley & $\mathrm{Cr}$ & $\mathrm{LC}$ & III & IV & III \\
\hline & Hordeum vulgare L. & Common barley & $\mathrm{He}$ & $\mathrm{LC}$ & 1 & 0 & $\mathrm{I}$ \\
\hline & $\begin{array}{l}\text { Milium pedicellare (Bornm.) Roshev. ex } \\
\text { Melderis }\end{array}$ & Milletgrass & Th & $\mathrm{NE}$ & 1 & I & 0 \\
\hline & Poa bulbosa L. & $\begin{array}{l}\text { Bulbous } \\
\text { bluegrass }\end{array}$ & $\mathrm{Cr}$ & $\mathrm{LC}$ & IV & II & $\mathrm{V}$ \\
\hline & Taeniatherum crinitum (Schreb.) Nevski & Medus-head & Th & $\mathrm{NE}$ & II & 1 & III \\
\hline & Trisetum flavescens (L.) P.Beauv. & Yellow oatgrass & $\mathrm{He}$ & $\mathrm{NE}$ & 1 & 1 & 0 \\
\hline \multirow[t]{2}{*}{ Polygonaceae } & Polygonum aviculare L. & $\begin{array}{l}\text { Prostrate } \\
\text { knotweed }\end{array}$ & $\mathrm{He}$ & NE & 1 & 0 & 1 \\
\hline & Rumex angustifolius Engelm. ex Meisn. & $\begin{array}{l}\text { Narrow-leaved } \\
\text { dock }\end{array}$ & $\mathrm{He}$ & NE & 1 & II & 0 \\
\hline \multirow[t]{9}{*}{ Ranunculaceae } & $\begin{array}{l}\text { Ceratocephalus testiculatus (Crantz) } \\
\text { Roth }\end{array}$ & $\begin{array}{l}\text { Curveseed } \\
\text { butterwort }\end{array}$ & Th & $\mathrm{NE}$ & II & 0 & II \\
\hline & Delphinium pallidiflorum Freyn & $\begin{array}{l}\text { Pale-flower } \\
\text { larkspur }\end{array}$ & $\mathrm{He}$ & $\mathrm{NE}$ & 1 & 1 & 0 \\
\hline & Ranunculus arvensis $\mathrm{L}$. & Corn buttercup & Th & $\mathrm{NE}$ & 1 & 1 & 1 \\
\hline & Ranunculus aucheri Clem. ex Boiss. & Buttercup & $\mathrm{Cr}$ & NE & II & II & III \\
\hline & $\begin{array}{l}\text { Ranunculus constantinopolitanus var. } \\
\text { villosus (DC.) Mobayen \& Z.Maleki }\end{array}$ & $\begin{array}{l}\text { Constantinople } \\
\text { buttercup }\end{array}$ & $\mathrm{He}$ & VU & 1 & 1 & 0 \\
\hline & $\begin{array}{l}\text { Ranunculus demissus Orphan. ex } \\
\text { Nyman }\end{array}$ & Buttercup & $\mathrm{Cr}$ & $\mathrm{NE}$ & I & $\mathrm{I}$ & 0 \\
\hline & Ranunculus oxyspermus Willd. & Buttercup & $\mathrm{Cr}$ & $\mathrm{NE}$ & 1 & 1 & 0 \\
\hline & Ranunculus pinardi Boiss. & Buttercup & Th & NE & 1 & I & 1 \\
\hline & Ranunculus sericeus Willd. & $\begin{array}{l}\text { Illyrian } \\
\text { buttercup }\end{array}$ & Th & $\mathrm{NE}$ & 1 & 1 & 0 \\
\hline Rhamnaceae & Paliurus spina-christi Mill. & Jerusalem thorn & $\mathrm{Ph}$ & $\mathrm{LC}$ & 1 & I & 0 \\
\hline Rosaceae & Amygdalus communis $\mathrm{L}$. & Sweet almond & $\mathrm{Ph}$ & $\mathrm{NE}$ & 1 & $\mathrm{I}$ & 0 \\
\hline
\end{tabular}




\begin{tabular}{|c|c|c|c|c|c|c|c|}
\hline & Cerasus microcarpa Boiss. & $\begin{array}{l}\text { Small-fruited } \\
\text { cherry }\end{array}$ & $\mathrm{Ph}$ & $\mathrm{NE}$ & 1 & IV & 0 \\
\hline & Cotoneaster morulus Pojark. & Cotoneaster & $\mathrm{Ph}$ & $\mathrm{NE}$ & 1 & 1 & 0 \\
\hline & Crataegus pontica K.Koch & Pontic hawthorn & $\mathrm{Ph}$ & $\mathrm{NE}$ & II & IV & I \\
\hline & $\begin{array}{l}\text { Prunus communis subsp. divaricata } \\
\text { (Ledeb.) Brandis }\end{array}$ & Plum & $\mathrm{Ph}$ & NE & 1 & 1 & 0 \\
\hline & Pyrus syriaca Boiss. & Syrian pear & $\mathrm{Ph}$ & $\mathrm{NE}$ & 1 & III & I \\
\hline & Rosa canina Sol. ex Bab. & $\begin{array}{l}\text { Common dog- } \\
\text { rose }\end{array}$ & $\mathrm{Ph}$ & NE & 1 & III & 0 \\
\hline \multirow[t]{11}{*}{ Rubiaceae } & Asperula arvensis $\mathrm{L}$. & Blue woodruff & Th & NT & $\|$ & 1 & ॥ \\
\hline & Callipeltis cucullaris Stev. & - & Th & NE & 1 & 0 & I \\
\hline & $\begin{array}{l}\text { Crucianella exasperata Fisch. \& } \\
\text { C.A.Mey. }\end{array}$ & Crosswort & Th & VU & 1 & 0 & I \\
\hline & $\begin{array}{l}\text { Crucianella gilanica subsp. } \\
\text { carduchorum Ehrend. \& Schönb.-Tem. }\end{array}$ & Crosswort & $\mathrm{He}$ & VU & 1 & I & 0 \\
\hline & Galium aparine L. & Cleavers & Th & NE & 1 & IV & 0 \\
\hline & Galium haussknechtii Ehrend. & Bedstraw & Th & NT & 1 & I & 0 \\
\hline & Galium humifusum M.Bieb. & Bedstraw & $\mathrm{He}$ & $\mathrm{NE}$ & 1 & I & 0 \\
\hline & Galium kurdicum Boiss. \& Hohen. & Bedstraw & $\mathrm{He}$ & NT & 1 & 0 & I \\
\hline & Galium setaceum Lam. & Bedstraw & $\mathrm{He}$ & NT & 1 & 0 & I \\
\hline & Galium tricornutum Dandy & Corn cleavers & $\mathrm{He}$ & $\mathrm{NE}$ & II & 0 & II \\
\hline & Galium verum $\mathrm{L}$. & Yellow bedstraw & $\mathrm{He}$ & $\mathrm{NE}$ & 1 & II & 0 \\
\hline Scrophulariaceae & $\begin{array}{l}\text { Parentucellia latifolia subsp. flaviflora } \\
\text { (Boiss.) Hand.-Mazz. }\end{array}$ & Red bartsia & Th & NE & 1 & 0 & I \\
\hline Thymelaeaceae & Daphne mucronata Royle & Kashmir daphne & $\mathrm{Ph}$ & NE & 1 & 1 & 0 \\
\hline Urticaceae & $\begin{array}{l}\text { Parietaria lusitanica subsp. } \\
\text { chersonensis (Láng) Chrtek }\end{array}$ & $\begin{array}{l}\text { Mediterranean } \\
\text { pellitory-of-the- } \\
\text { wall }\end{array}$ & Th & $\mathrm{NE}$ & 1 & 0 & I \\
\hline Violaceae & Viola modesta Ball & Modest violet & Th & $\mathrm{NE}$ & 1 & 1 & 0 \\
\hline
\end{tabular}

